Portland State University

PDXScholar

1972

\title{
A taxonomic study of the marine algae of Netarts Bay, Oregon
}

Charles Jerome Kunert

Portland State University

Follow this and additional works at: https://pdxscholar.library.pdx.edu/open_access_etds

Part of the Botany Commons, Marine Biology Commons, and the Plant Biology Commons Let us know how access to this document benefits you.

\section{Recommended Citation}

Kunert, Charles Jerome, "A taxonomic study of the marine algae of Netarts Bay, Oregon" (1972). Dissertations and Theses. Paper 969.

https://doi.org/10.15760/etd.969

This Thesis is brought to you for free and open access. It has been accepted for inclusion in Dissertations and Theses by an authorized administrator of PDXScholar. Please contact us if we can make this document more accessible: pdxscholar@pdx.edu. 
AN ABSTRACT OF THE THESIS OF Charles Jerowe Kunert for the Master of Science in Biology presented July I, 1972.

Titie: A Taxonoric Study of the Larine MIgae of Netarts Bay, Orogon.

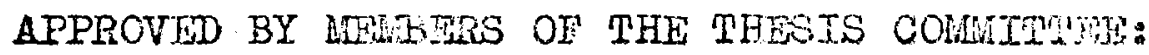

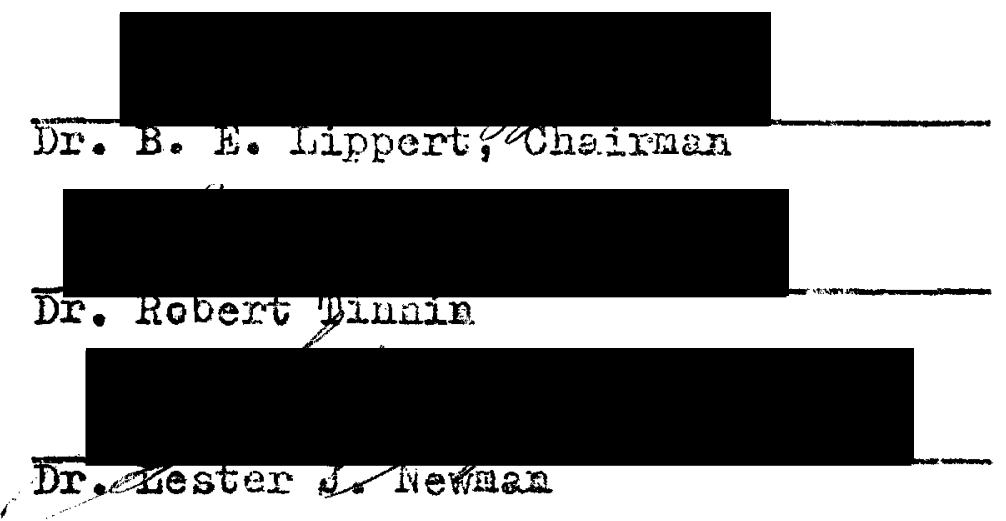

Gathering taxonomic data is fundamental to any bialogical or ecological research. It was the intent of this paper to increase the storehouse of taxonomic information by studying the marine algae of one section of the Oregon coastline. Netarts fay was chosea because of its accessibility and gexexaly prixitive nature. It is in an area of Oregon largely untouched by phycologists and so offered an opportunity for original research. Techniques of collecting and preserving specimens were kept as sinple as possible, thus allowing a proportionately greater amount of the available tire to be apent in the classification of the organisas. The body 
of this paper is, therefore, an annotated list of the 2lgae collected and identified. A total of 78 species were identified, the majority belonging to the division Rhodophyta ( 45 of the 78). An effort was nade in collecting to be as thorough as possible. Algae ranging in habitat all the way from the spray zone to the depths of Netarts Bay were included. However, while the collection is comprehensive, because of the great size of the Bay it is undoubtedly incomplete. Only further research can identify which algae have been overlooked or omitted. Photographs are in ovidence throughout much of the text. It is hoped that they will illustrate some of the forms which might be found only in this region and also, as accurately as possible, to aid in the identification of species elsewhere. 
A TAXONOMIC STUDY OF PHE MARTNE ALGAE

OT NEYARTS BHY, OREGON

by

CHARIESS JEROHE KUNHRT

A thesis submitted in partial fulfillment of the requirements for the degree of

MASTER OF SCIENCE

in

BIOLOGY

Portland State University

1972 
TO THE OFEICE OF GRADUATE STUDIES:

The members of the Comnittee approve the thesis of Charles Jerome Kunort presented July 1, 1972.

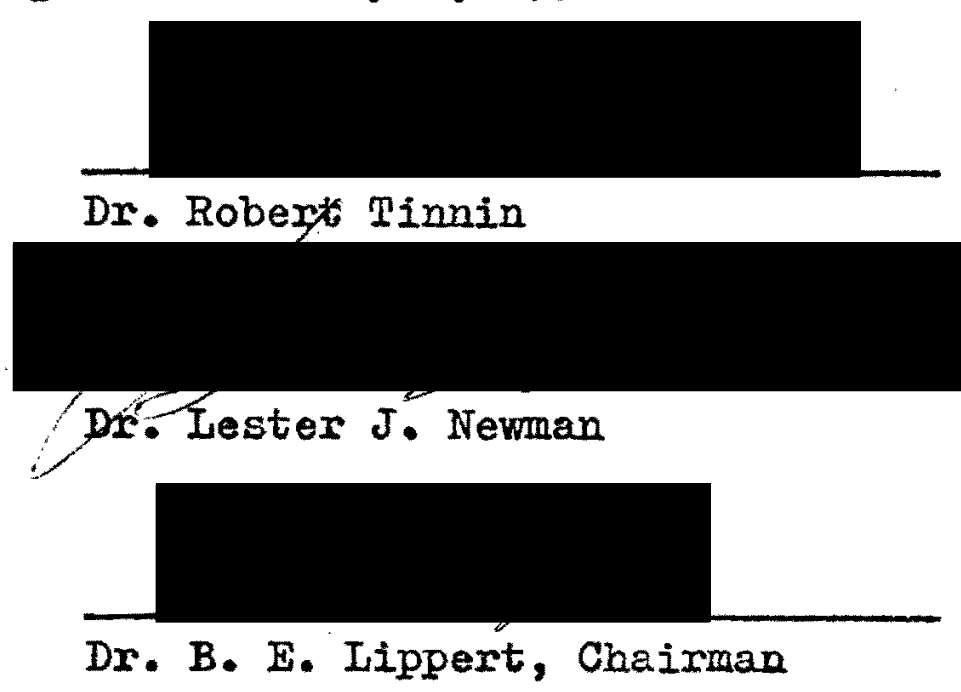

APPROVED:

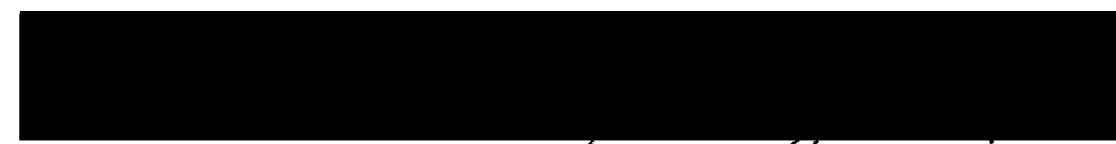

Dr. Earl Fisher, Head, Deparfhent of Biology

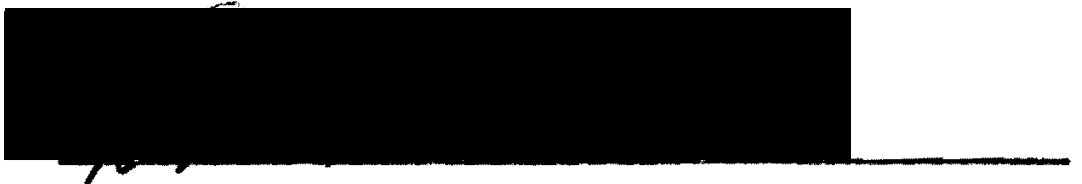

David T. Clark, Dean of Graduate Studies 
TABLE OF CONTENTS

PAGE

PREFACE . . . . . . . . . . . . . . . i i ACKROWLEDGLIENIS . . . . . . . . . . . . v IIST OF FIGURES ................... vii

CHAPTER

I GEOGRAPHIC FEATURES AND TOPOGRAPHY OF THE NETARTS BAY, OREGON REGION •. • . . . . . . . 1

- II MATERIALS AND METHODS . . . . . . . 6

Collecting ............. 6

Preservation ........... 6

Identification . . . . . . . . 8

Illustrations . . . . . . . . 8

III AN ANNOTATED LIST OF THE. MARINE ALGAE OF NEIARTS BAY, OREGON . . . . . . . . . 12 Division: Chlorophyta . . . . . . 12 Division: Phaeophyta . . . . . . 25 Division: Rhodophyta . . . . . . 30 REFERFANCES APPENDIX: KEY TO THE GENERA ........... 68 


\section{PREFACE}

In the realm of taxonomic literature dealing with marine algae, there is a virtual dearth of literature concerning the northern Oregon coast. Although the Pacific coastline is fairly well represented in the literature for most of its length from Alaska to Mexico, the northern Oregon coast has been relatively untouched by phycologists to date. Setchell and Gardner (1903, 1919-1920, 1933, 1937), in their pioneering work, did cover the entire Pacific Coast of North America, but made few references to the northern Oregon beaches in specific. Alaska, British Columbia, and Washington have been covered by Kylin (1925) and Scagel $(1957,1966,1967)$ who is currently working primarily with the Phasophyta and Rhodophyta of this region. Doty $(1947 \mathrm{a}, 194 \mathrm{bb})$ and his colleagues from the University of Oregon Rarine Biological Station at Charleston, Oregon have covered the southern Oregon coast. Smith (1944) thoroughly covered the Monterey Peninsula region of California, and was folloved by Hollenberg and Abbott (1965, 1968) in this area. Abbott (1961, 1965, 1967, 1968, 1969) has concentrated her efforts around the Hopkins Marine Station, Pacific Grove, California, while Hollenberg $(1943,1944,1945,1961)$ worked largely in California and Mexico. Mexico also was extensively covered 


\section{ACKNOWLEDGMENIS}

The author takes this opportunity to acknowledge with much gratefulness the help of Dr. B. E. Lippert in directing first feeble efforts in this work, the help of Dr. Isabella Abbott in identifying certain very troublesome specimens, Mir. Roy Derickson in photographic assistance, and my wife, Pat, for enduring my many trips to the coast and long hours away from home while completing my research and paper. 


\section{IIST OF FIGURES}

FIGURE

PAGE

1. Topographical isap of the Netarts Bay area showing collecting sites as Zone 1, Zone 2, etc. (Photographs of U.S. Geological Survey Map). . . . 5

2. Rhizoclonium tortuosure. (10x) ....... 13

3. Cladophora bertolonii v. hamosa. (10x) . . . . 14

4. Cladophora glaucescens. (10x) . . . . . 15

5. Monostroma zostericol2, showing a surface view of the thallus. $(40 x)$. . . . . . . . . 16

6. Monostroma oxyspermum, showing a surface view of the thallus. $(40 x)$. . . . . . . . . 16

7. Blidingia minima $v$ minima, showing a surface view of the thallus. (97x) . . . . . . 27

8. Enteromorpha prolifera, showing a surface view of the thallus. $(40 x)$. . . . . . . . . 18

9. Enteromorpha prolifera. (1/2x) . . . . . . 19 10. UIva angusta. (1/2x) ............. 21 11. Ulva fenestrata. $(1 / 2 x)$. . . . . . . . 22

12. UIva stenophylla. $(1 / 2 x)$. . . . . . . 24

13. Ectocarpus variablis, showing branching of filaments and plurilocular gainetangia. (10x) . . . . 25

14. Ectocarpus variablis, showing an enlargement of 2 plurilocular gametangium and a portion of the fila- 
viii

ment. $(40 x)$................. 26

15. Ectocarpus confervoides $\mathbf{v}$ confervoides, showing the branching of the filaments. (10x) . . . . 27

16. Desmerestia munda. $(1 / 2 x)$. . . . . . . 28

17. Desterestia herbacea. (1/2x) . . . . . . . 29

18. Sargassum muticun. (1/2x) . . . . . . . . 31

19. Bangia vemicularis, showing uniseriate upper portion of the thallus. (10x) ........ 32

20. Bangia vermicularis, showing corticated lower portion of the thallus. (40x) ....... 32

21. Smithora naiadum. Surface view of the thallus. (40x) ................... 33

22. Porphyra lanceolata. (1/2x) . . . . . . 34

23. Cryptosiphonia woodii. (1/2x) . . . . . . 35

24. Prionitis andersonii. (1/2x) . . . . . 37

25. Gracilariopsis sjoestedtii. $(1 / 2 x)$. . . . 38

26. Gigartina volans. $(1 / 2 x)$........... 41

27. Gigartina papillata. (1/2x) . . . . . . 42

28. Gigartina harreyana. (1/2x) . . . . . . . 43

29. Gigartina californica. (1/2x) . . . . . . 44

30. Gigartina exasperata. (1/2x) . . . . . . 45

31. Iridaea heterocarpa. (1/2x) . . . . . . 47

32. Iridaea cordata. $(1 / 2 x)$. . . . . . . 48

33. Iridaea whidbeyana. (1/2x) . . . . . . 49

34. Ptilota filicina. $(1 / 2 x)$......... 51

35. Polyneura latissira. (1/2x) . . . . . . 52 
36. Hymenena setchellii. (1/2x) . . . . . . 54

37. Hymenena flabelizgera. $(1 / 2 x)$. . . . ... 55

38. Hymenena kylinii. (1/2x) . . . . . . . 56

39. Polysiphonia pacifica, showing two of the four pericentral cells that form the major portion of the thallus. (40x) . . . . . . . . 57

40. Polysiphonia paniculata, showing the scar cell (point "A"). (40x) ........... 58

41. Polysiphonia paniculata, showing the characteristic configuration of tetraspores. (10x) . . . 58 42. Polysiphonia paniculata. (1/2x) . . . . . 59 43. Pterosiphonia dendroidea. (2.5x) . . . . 60 44. Odonthallia floccosa. (1/2x) . . . . . . . 61 45. Odonthallia oregona. $(1 / 2 x)$. . . . . . . 62 


\section{CHBPIER I}

\section{GEOGRAPHTC FEATURES AND TOFOGRAPHY OF THE NEWLRTS SAY, OREGON REGION}

Netarts Bey is located on the northern Oregon coast, some seven miles west of the town of Tiliamook. The Bay is bounded to the north by the projection of Cape Meares into the Pacific Ocean, and to the south by Cape Lookout. The western shore of the bay is a long, narrow wedge of sand spit which runs along a north-south path and forms the mouth of the Bay where it approaches the land in the area just north of the town of Netarts. The eastern shoreline is largely the last vestiges of the Coast Range undulating down to the ocean.

Netarts Bay is a vexy shallow bay, and much of it is exposed at low tide. The southern half of Netarts Bay is composed of silt deposition and is very muddy. Travel by foot in this area of the Bay is very difficult due to the soft nature of the mud. The vestern region, as well as that of the northern half of the Bay is largely sand, with the eastern shore sand and natural rocks. Only a narrow channel is open to navigation at low tide. The area around Netarts Bay is largely undeveloped, and pollution characteristic of other estuarine areas 
along the coast is, for the most part, absent. The only inroads into the ecological balance of the Bay have come as a result of the retaining wall built along the eastern shore, and the boat jetties constructed south of the town of Netarts. Both of these features are constructed of large basaltic rocks which have been hauled into the area. These rocks are not native to this region, although the Bay is couched between two lava flows which form Cape Meares and Cape Lookout.

Twelve separate streams bring fresh water into the Bay, thus creating special habitat problems for organisms living in the immediate vicinity of the flow of these streams into the salt water of the Bay. These areas were found to have their own peculiar types of marine flora. Collecting stations were chosen by the author to cover all of the various topographical factors which might influence the type of algae found in the area. Six large collecting stations were set up as follows: Zone 1: The extreme northern shore of the Bay, immediately in front of the town of Netarts, and stretching from the area just north of the boat jetties to Fall Creek. This area is characterized by native rocks approximately 5 to $30 \mathrm{~cm}$. in diameter buried in sand. Many clam-diggers frequent this region, and hence there is much turnover of the rock and sand. Zone 2: The rocks that form the boat jetties. These rocks were evidently placed here some eight years 
ago, and since that time have been repopulated by a large variety of algal types. This area and Zone 1 possess the greatest variety of algal species. zone 3: The rocks which form the retaining wall running from the boat jetties to Whiskey Creek. During the winter months, the rocks in this area were found to be largely barren. Zone 4: The extreme southeastem shore of the Bay. This is an area of much mud, fallen logs, and grass running into the Bay proper. Zone 5: The southwestern shore of the Bay, running from Cape Lookout State Park to two miles out on the spit. It is similar in edaphic factors to Zone 4, but has a different exposure to the sun. Zone 6: The northern tip of the sand spit. This area is 2lmost entirely exposed at low tide, and is formed of sand brought out of the Pacific by wave action and wind. very few natural rocks occur in this region.

Because of the sand spit, wave action is quite limited in Netarts Bay itself. Only in the most ferocious winter storms do waves reach a size which would affect the flora on the rocks along the eastern shore. The western shore is protected from wave action because the prevailing winds are resterly, and the sand spit blocks them effectively.

If one were to characterize the Bay in terms of its variety of algal life, one would have to conclude that for the most part Netarts Bay is fairly desolate. 
The muddy south end of the Bay is largely covered by mats of Rhizoclonium, while Fucus predominates along the shoreline. The sandy areas of the Bay are usually heavily populated with Porphyra, Ulva, Enteromorpha, and Blidingia which may float into the region. The rocky areas of the Bay, especially in Zones 1 and 2 , are the most heavily populated areas in terms of variety of species, with Laminaria, Sargassum, and Ulva along with several species of Gigartina bejng the dominants. 


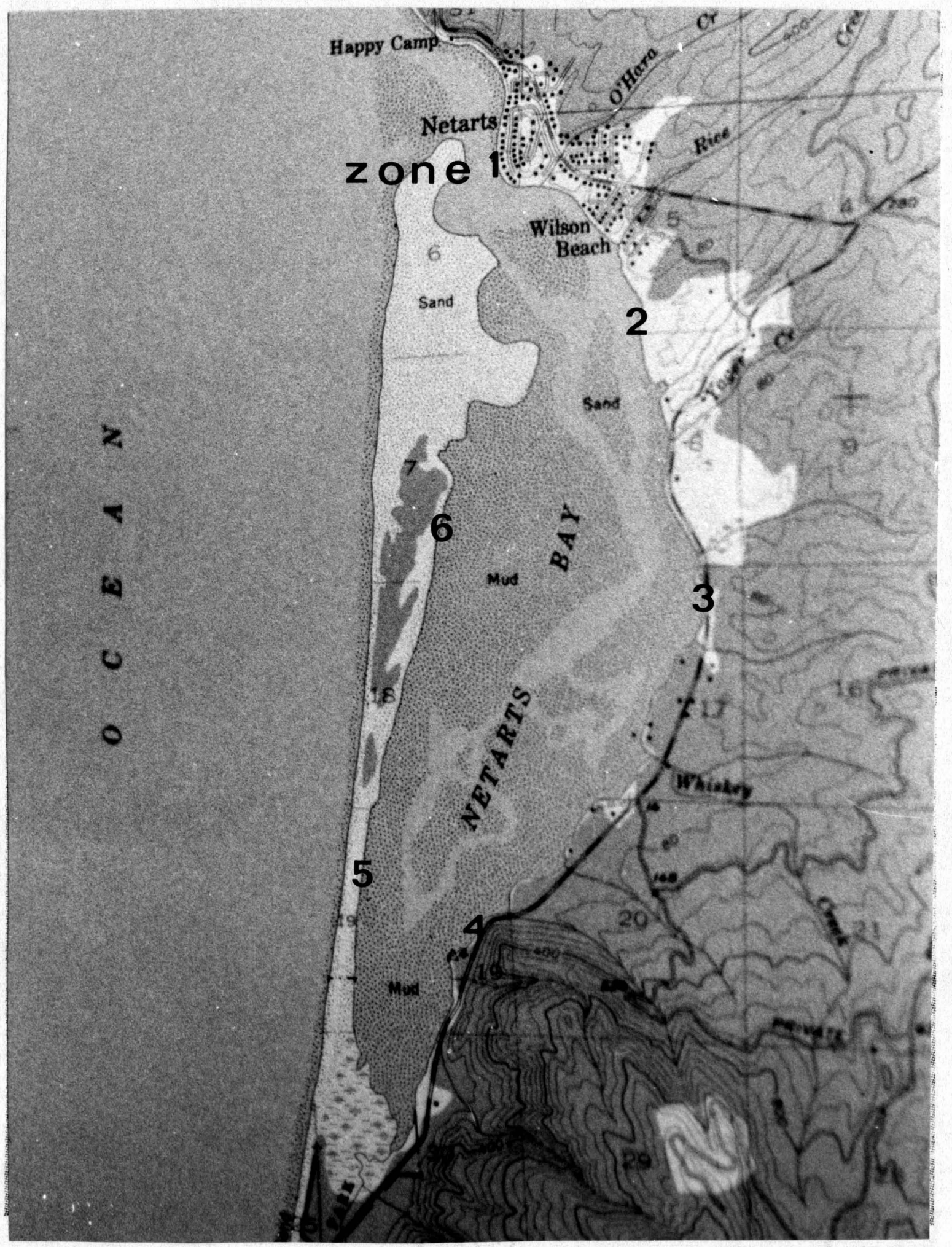

Figure 1. Topographical map of the Netorte Bay area showing collecting sites 25 Zone 1 , Zone 2, eto. (Photograph of U.s. Geologiod Survey Map). 


\section{CHAPTER II}

\section{MAMERIALS AND METHODS}

\section{COLLECTING}

An attempt was made to reach each of the different collecting stations once during each of the seasons from winter to summer. Hence three complete circuits of the Bay were made ciuring the collecting trips.

The collection procedure followed in pursuit of these algae involved a fairly simple and unsophisticated approach. The collector and any assistants started at one end of a collecting station and systematically combed the station, both in the water and on the beach area for any new specimens. All collections were perforred from one hour before to one hour after low tide. Specimens were placed in collection jars numbered with an identifying number for future reference. Notations were made in a collection booklet for each number entered including location, physical surroundings, edaphic factors, biotic surroundings, frequency, color, size, and other pertinent information.

\section{PRESERVATION}

Two basic types of preservation methods were 
attempted in this research: wet and dry. The wet preservation involved the use of $10 \%$ formalin in sea water. FAA was utilized as a preservative, but was found to be much too caustic, especially on the Rhodophyta. With FAA all color was gone from specimens within one day, while 10\% formalin was found to preserve texture and color indefinitely if the specimen was not placed in the sun or any source of heat or light other than the sun. The ary preservation method involved placing specinens on regular grade student herbarium mounting paper (obtained from the Carolina Biological Supply Co.). The initial mounting was done under water, where fragile specimens could be reanipulated with a camel hair brush and arranged properly on the herbarium paper. These were then placed under a layer of single thickness cheesecloth, put between two blotters and two pieces of corrugated cardboard, and pressed in an herbarium press. The blotters were replaced with fresh ones once every 24 hours for three days. Usually the algae will stick well to the herbarium paper due to the glue-like mucilage which permeates most algal tissues, but in cases where they did not or where the specimen was particularly fragile, Archer's Adhesive was used to permanently mount them to the sheet.

of the two methods, the latter is better for display purposes and shows the general shape of the alga, 
whereas the former methed is better in cases where micrescopic studies are necessary to reveal the true identity of the species.'

\section{IDENTIFICATION}

Identification was carried out through various keys, but principally through soveral very helpful references. These included setchell and Gardner (1920) for the Chlorophyta and Phaoophyta, Sxith (1944) for all the Rhodophyta in particular, and Scagel (1966). Nomenclature utilized is that of Hollenberg and Abbott in thoin rovision of Smith's work on the Monteres Poninsula.

\section{IIUUSTRATIONS}

Microphotographs found in this manuscript were taken on a Carl Zeiss phaso-plano objective nicroscope. Kodak Panatomic-X and Verichrome Pan filns were utilized in a Rada microscope camera attachment. All specimens were compared to a Bausch and Lomb optical micrometer for size checks.

Full size illustrations were photographed with a Praktica Nova $B$ and Tri-x Pan filin. 


\section{TABLE I}

DISTRIBUTION OF SPECIES AT

COLTECTING STATIONS IN

NETARTS BAY

$$
1971
$$

Algal Species

Zones

1

3

4

5

6

CHLOROPHYTA

Rhizoclonium implexum

Rhizoclonium tortuosum

Cladophora ovoidea

Cladophora flexuosa

Cladophora gracilis

cladophora bertolonii

v. hamosa

Cladophora glaucescens

Spongonorpha spinescens

Monostroma zostericola

Monostroma oxyspermum

Blidingia minima $v$. minima $x$

Blidingia minima v subsalsa

Enteromorpha linza

Enteromorpha intestinalis

v. clavata

Enteromorpha prolifera

Enteromorpha tubulosa

Enteromorpha flexuosa

Ulva angusta

UIva fenestrata

Ulva expansa

Ulva rigida

Ulva stenophylla

Ulva vexata

Ulva dactylifera

Ulothrix implexa

$\begin{array}{lllll}\mathbf{x} & \mathbf{x} & \mathbf{x} & \mathbf{x} \\ \mathbf{x} & \mathbf{x} & & \end{array}$

PHAEOPHYTA

Ectocarpus variablis

Ectocarpus confervoides

$\nabla$. confervoides

Phaeostrophion irregulare

Desmerestia munda

Desmerestia herbacea

Laminaria saccharina

$\begin{array}{llll} & & \mathbf{x} & \\ \mathbf{x} & \mathbf{x} & \mathbf{x} & \mathbf{x} \\ \mathbf{x} & & \\ & \mathbf{x} & & \\ & \mathbf{x} & \mathbf{x} & \mathbf{x} \\ \mathbf{x} & & \mathbf{x} & \mathbf{x} \\ & & & \mathbf{x}\end{array}$

v. saccharina

Sargassum muticum

$x \quad x$

$x$

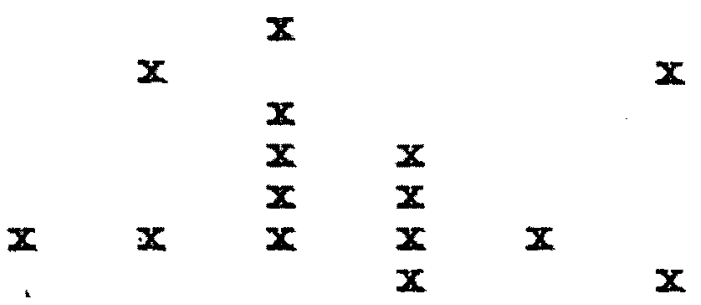

Fucus gardneri v. abbreviatus

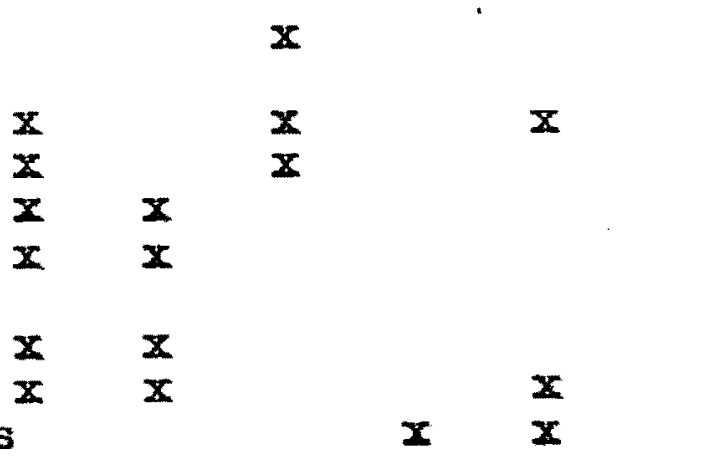


TABLE I continued

Algal Species

Zones

\begin{tabular}{|c|c|c|c|c|c|c|}
\hline & 1 & 2 & 3 & 4 & 5 & 6 \\
\hline \multicolumn{7}{|l|}{ RHODOPHYNA } \\
\hline Bangia vermicularis & & $\mathbf{x}$ & & & & \\
\hline Smithora naiadum & $\mathbf{x}$ & & $\mathbf{x}$ & & & \\
\hline Porphyra perforata & & $\mathbf{x}$ & & & $\mathbf{x}$ & $x$ \\
\hline $\begin{array}{l}\text { Porphyra lanceolata } \\
\text { Cryptosiphonia woodii }\end{array}$ & $\begin{array}{l}\mathbf{x} \\
\mathbf{x}\end{array}$ & $\mathbf{x}$ & $x$ & $\mathbf{x}$ & & \\
\hline Lithothamnion californicum & & $\bar{x}$ & & & & \\
\hline $\begin{array}{l}\text { Dermatolithon dispar } \\
\text { Corallina officinalis }\end{array}$ & $x$ & & & & & \\
\hline จ. chilensis & $\mathbf{x}$ & & & & & \\
\hline Prionitis lanceolata & & & & & & $\mathbf{x}$ \\
\hline Prionitis andersonii & $\mathbf{x}$ & $\mathbf{x}$ & & & & \\
\hline Callophyllis oregona & $\mathbf{x}$ & & & & & \\
\hline Gracilariopsis sjoestedtii & $\mathbf{x}$ & $\mathbf{x}$ & & & $x$ & \\
\hline Ahnfeltia plicata & $\mathbf{x}$ & $x$ & & & & \\
\hline Ahnfeltia concinna & $\mathbf{x}$ & & & & & \\
\hline Gymnogongrus leptophyllus & & & & $\mathbf{x}$ & $\mathbf{x}$ & \\
\hline Gigartina cristata & & $\mathbf{x}$ & & & & \\
\hline Gigartina exasperata & $\mathbf{x}$ & & $\mathbf{x}$ & $\mathbf{x}$ & $\mathbf{x}$ & \\
\hline Gigartina californica & $x$ & & $\mathbf{x}$ & & & \\
\hline Gigartina papillata & & $\mathbf{x}$ & & & & \\
\hline Gigartina volans & & $\mathbf{x}$ & $\mathbf{x}$ & & & \\
\hline Gigartina harvejana & & $\mathbf{x}$ & & & & \\
\hline Rhodoglossum affine & & & $\mathbf{x}$ & & & \\
\hline Iridaea heterocarpa & & $\mathbf{x}$ & & & & \\
\hline Iridaea Iineare & & $\mathbf{x}$ & & & & \\
\hline Iridaea cordata & $\mathbf{x}$ & $\mathbf{x}$ & $\mathbf{x}$ & & & \\
\hline Iridaea whidbeyana & & $\mathbf{x}$ & & & & \\
\hline Plocamium coccineum & & & & & & \\
\hline Y. pacificum & $\mathbf{x}$ & & & & & $\mathbf{x}$ \\
\hline $\begin{array}{l}\text { Antithamnion kylinii } \\
\text { Platythamion viliosum }\end{array}$ & $\mathbf{x}$ & & & $x$ & & \\
\hline $\begin{array}{l}\text { Platythamnion villosum } \\
\text { Microcladia coulteri }\end{array}$ & $\mathbf{x}$ & $\mathbf{x}$ & & 2 & & $\mathbf{x}$ \\
\hline Microcladia borealis & & & & & & $x$ \\
\hline Ptilota hypnoides & $\mathbf{x}$ & & & & & \\
\hline Ptilota filicina & $\mathbf{x}$ & $\mathbf{x}$ & & & & \\
\hline Polyneura latissima & & $\mathbf{x}$ & & & & \\
\hline Hyrenena setchellii & $\mathbf{x}$ & & & & & \\
\hline Hymenena Ilabelligera & $\mathbf{x}$ & $\mathbf{x}$ & & & & \\
\hline Hymenena kylinii. & $\mathbf{x}$ & & & & & \\
\hline Polysiphonia pacifica & $x$ & & & & & \\
\hline Polysiphonia dictyurus & & & $\mathbf{x}$ & & & \\
\hline Polysiphonia paniculata & $\mathbf{x}$ & & $\mathbf{x}$ & & $x$ & \\
\hline Polysiphonia collinsii & $\mathbf{x}$ & $\mathbf{x}$ & $x$ & & $\mathbf{x}$ & \\
\hline Pterosiphonia dendroidea & $\mathbf{x}$ & $\mathbf{x}$ & & & & \\
\hline
\end{tabular}


TABLE I Continued

Algal Species

Zones

\begin{tabular}{lcccccc} 
& 1 & 2 & 3 & 4 & 5 & 6 \\
\hline $\begin{array}{l}\text { Odonthallia floccosa } \\
\text { Odonthallia oregona }\end{array}$ & $x$ & $x$ & $x$ & & & \\
Laurencia spectabilis & $x$ & $x$ & & &
\end{tabular}


CHAPTER III

AN ANNOTATED LIST OF THE MARINE AIGAE

OF NETARTS BAY, ORTGON

I. DTVISION: CHLOROPHYTA

Class: Chlorophyceat

Order: Cladophorales

Rhizoclonium Kuetz.

Key to the Species

Filaments soft, forming fleecy masses on mud, 20-30 in diameter, segments about 2 times as long as broad . . •.......... Rhizoclonium implexum(I) Filaments rigid, contorted, dark green, forming rope-like entangled masses on mud or sand, 50-80 $\mu$ in diameter, segments 1-2 times as long as broad, occasionally longer.

(1) Rhizoclonium implexum (Dillw.) Kuetz.

On mud in zone 3 . Collected only June 29. Setchell and Gardner (1920), p. 183. Collection number: 173

(2) Rhizoclonium tortuosum (Dillw.) Kuetz. Fig. 2. Very common throughout the range, sometimes covering most of the mudflats at the south end of Netarts Bay. Setchell and Gardner (1920), p. 185. Collection numbers: $13,42,50,60,74,87$.

Cladophora Kuetz.

\section{Key to the Species}

1. Filaments containing both cylindrical and barrel shaped segments in the same filament . . Cladophora ovoidea(I) 1. Filaments with similar shaped segments throughout 2. 2. Main filaments distinctly flexuous.

- * * * - Cladophora flexuosa (2) 2. Main filaments essentially straight.... 3. 


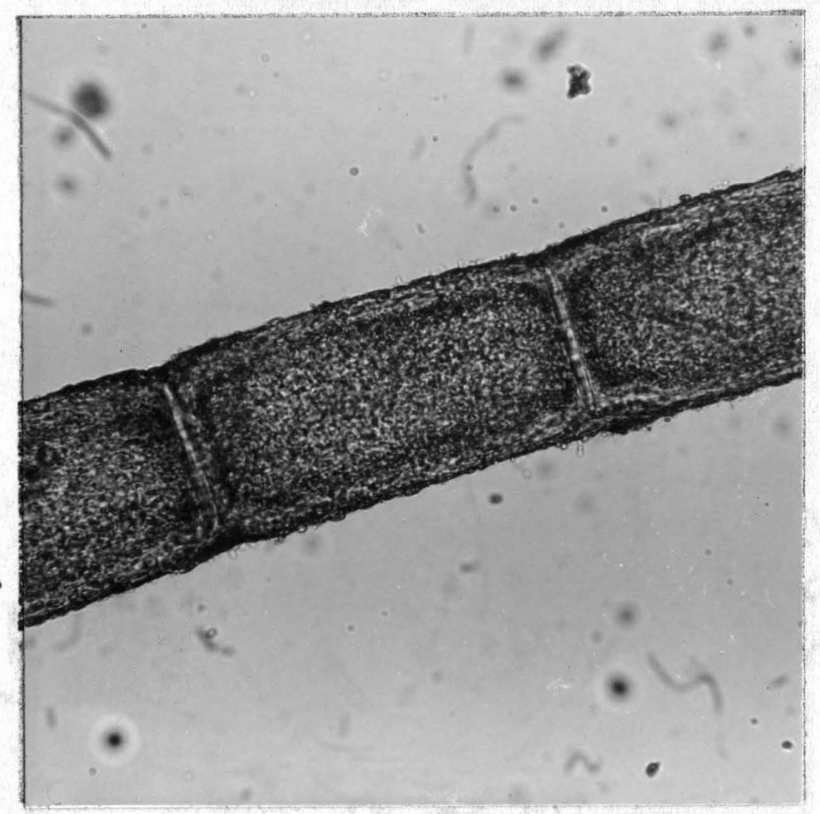

Figure 2. Rhizocloniura tortuosum. ( $10 \mathrm{x}$ )

3. Main filaments coarse, up to $150 \mu$.

- . . . . . Cladophora gracilis $(3)$ 3. Main filaments slender, not over $80 \mu \cdots \cdots$. . 4. Ramuli curved ................ - *: - Cladophora bertolonii ve hamosa (4) 4. Ramuli straight.. Cladophora glaucescens (5)

(I) Cladophora ovoidea Kuetz. In slightiy erect tufts attached to rocks in rad. Collected only on July 12. Setchell and Gardner (1920), p. 214. Collection number: 211.

(2) Cladophora flexuosa (Griff.) Harv. In association with Polysiohonia collinsii on rocks in the upper littoral zone around the boat jetty. Collected only March 13. Collection number: 46. Setchell and Gardner (1.920), p. 217.

(3) Cladophora gracilis (Griff.) Kuetz. In tufts on rocks in the mudflats of zone 4. Identified by Dr. Isabella Abbott. Setchell and Garaner (1920), p. 216. Collection number: 171.

(4) Cladophora bertolonii v. harosa (Kuetz•) Ardiss 
Forming a reddish-brown rat (when dry) on the upper surface of the banks of the south end of the Bay in zone 4 and 5. At about $+3.0 \%$. Very abundant. Setchell and Gardner (1920); p. 218. Collection numbers: 48,80 ,

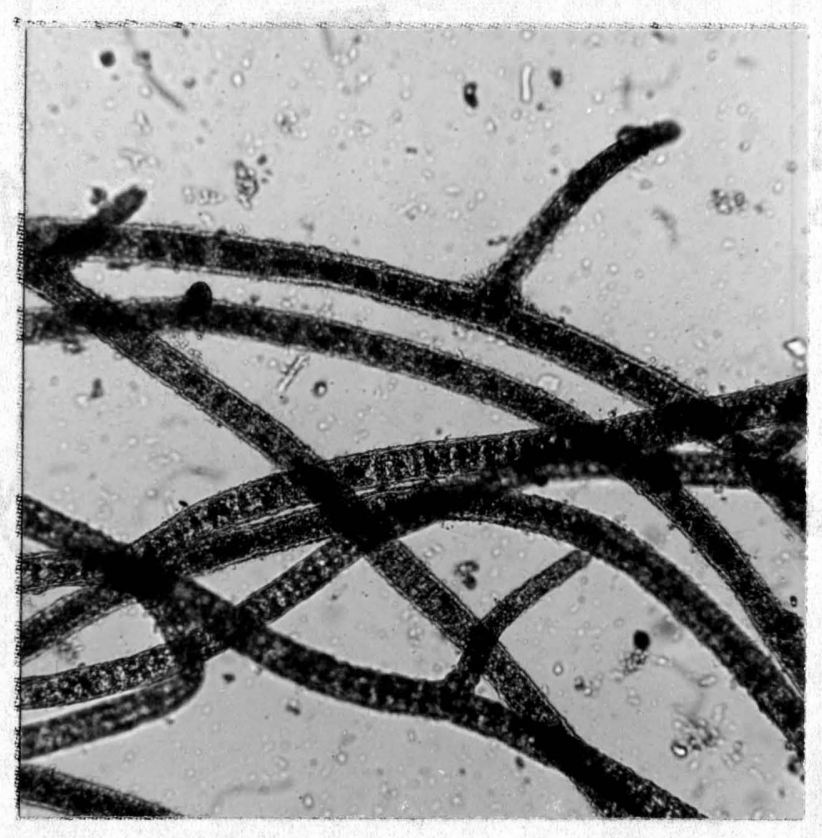

ELgure 3. Olagophora bertolont $v \cdot$ hemoga. (10x)

(5) Cladophora Llancesoens (Griff. Hsw.

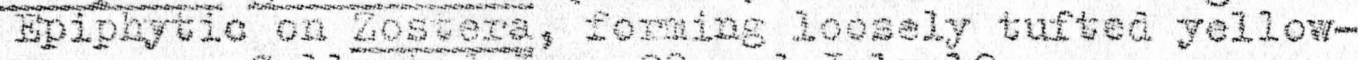
green masses. collected tune 29 and July 12.

Setchell and Gardner (1920), $\mathrm{p}, 219$.

Collection numbex: 169,203 .

Spongomorpha spinescens Kuetz

In erect tuts at $-1.0^{\circ}$. Green and entangled.

collected only June 12 near the boat jetty:

Setchell and Gardner (1920), p. 229.

Collection number: 144 .

Ordex: Ulvales

Monostroma Thur.

Key to the Species

Epiphytic on Zostera ... Monostroma zostericola(1) 


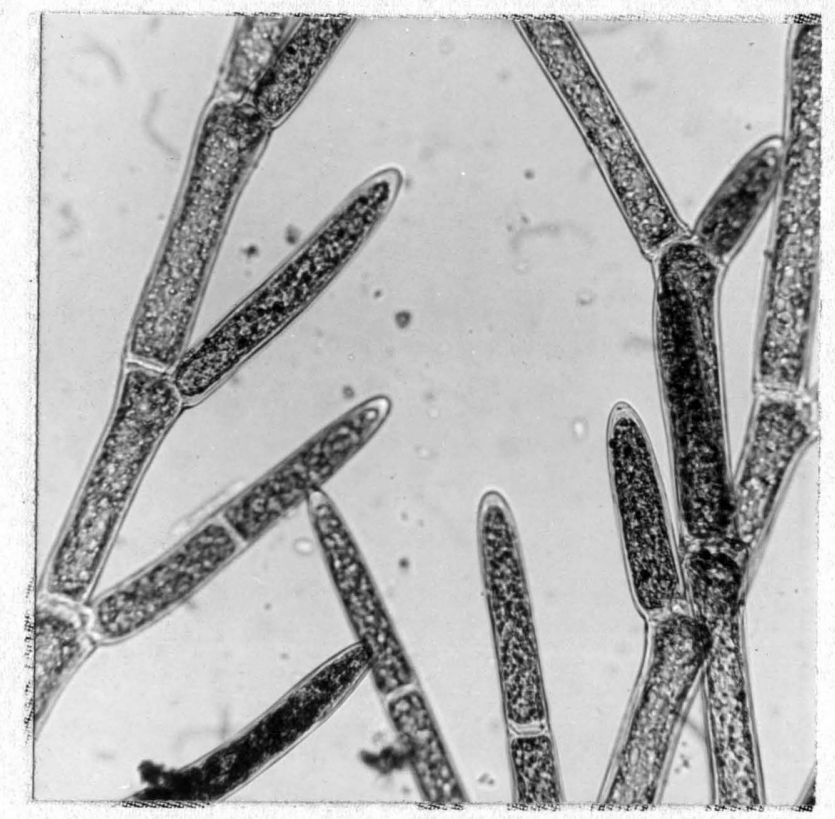

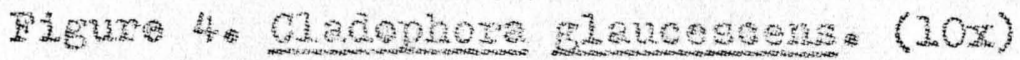

Growing on rooks on free-floating

(1) Monostroma zostericola pizden

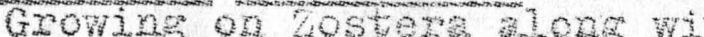
two species of Botocarous. 10 a heiblo of 4 cmo collected only June 29 . Setchell and Gardnex (1920), p. 238. Collection number: 163 .

(2) Monostrong oxyspergura (Kuetz.) Doty Growing on rocks or free-1loving in fresh-water strean that would be covered at high tide with salt water. Collected in zone 4 on Majoh 21 . Setchell and Gardnex (1920), p. 240m-241.

Scagel (1966), p. 39.

Collection numbers: $61,62,67$.

Blidingia Kylin

Key to the Varieties

Frond tubular, unbranching. Blidingia rinima $v$. Minima(1) Frond branching... Blidingia ninima v subsalsa (2) Blidingia minima (Nägeli) Kylin v. minima Fig. 7. Comon throughout the Bay at upper littoral to lower 


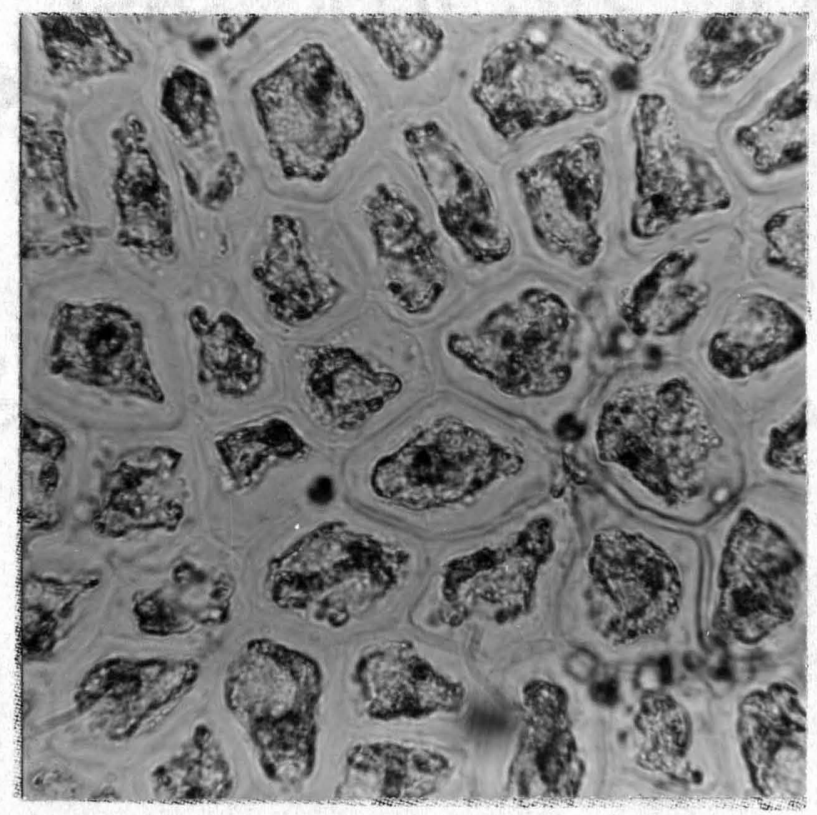

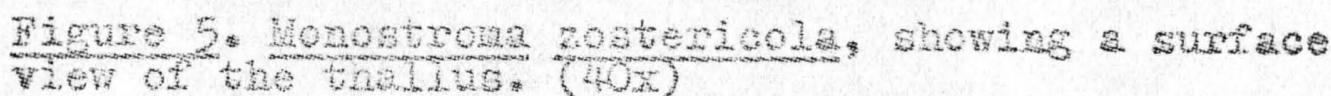

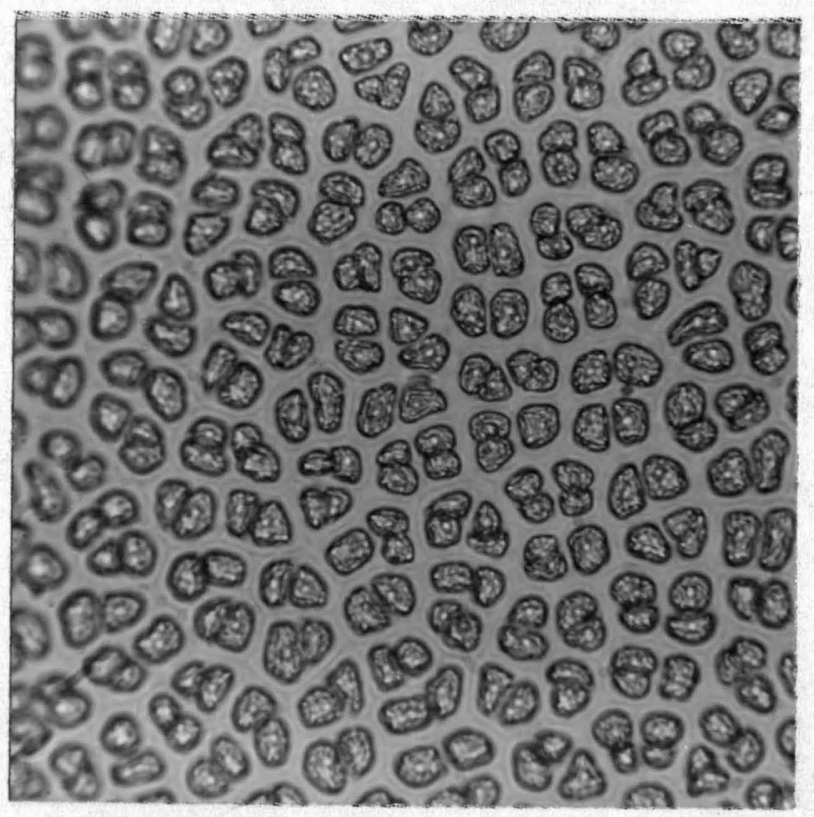

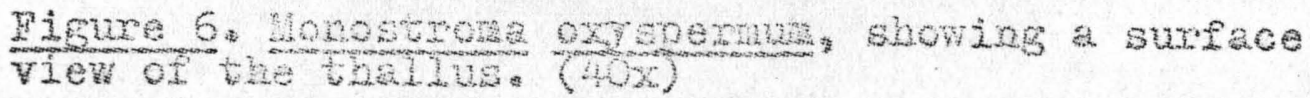

inter-tidal zone, sttachod to wocks os $108 \mathrm{~s}$ in sand or mud. Setchel1 and Gardner $(1920), 2 * 249-250$. 
Scagel (1966), $0.42-43$.

165.

Collection numbers: $9,12,59,64,65,66,92,93$,

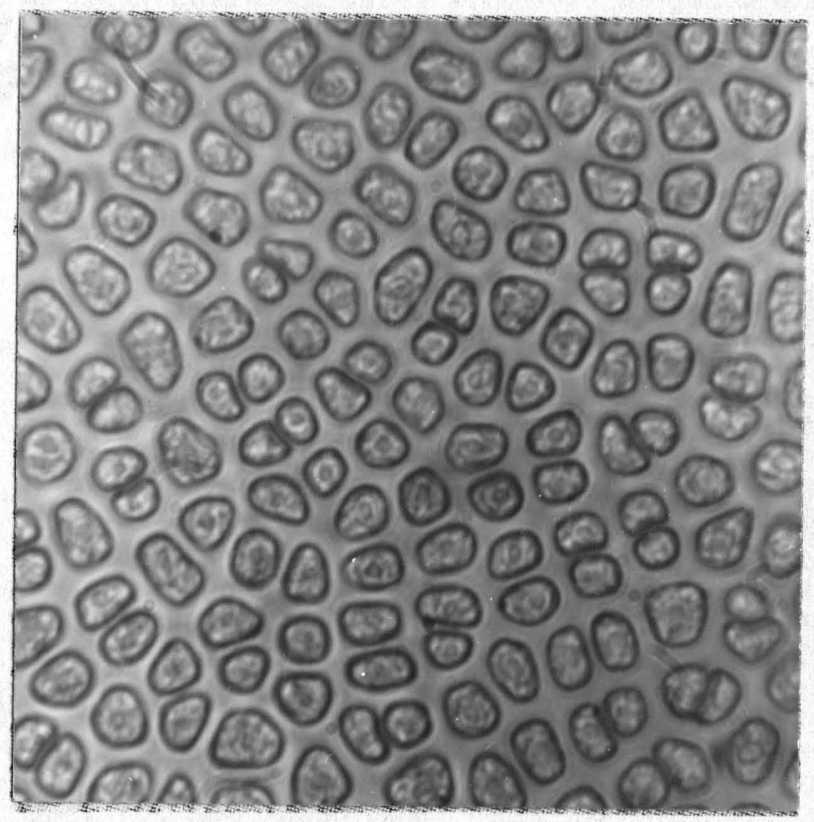

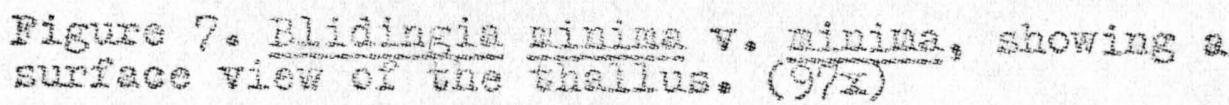

(2) Blidingia minina v Eubselsa (Kjellnan) Songel

Combon in the muday regions of zones 4 and 5 , exposed at lon tide.

Setohell and Gardnex, (1920), p. 249.

Scagel (1966), p. $43:$

Collection numbers: 63,84 .

Enteromoroha Ijnk

Key to the Species

1. Frond distincty compressed into a lanceolate blade.

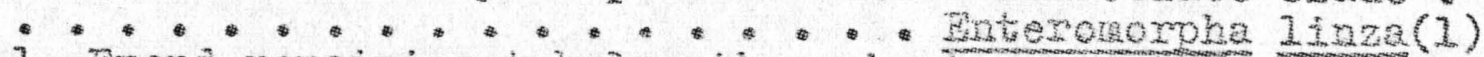
1. Frond reaining tubulax throughout, even though it may

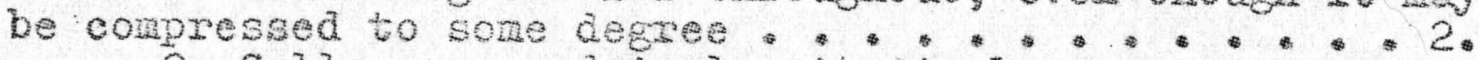
2. Cells amranged in longituainal rows in much of

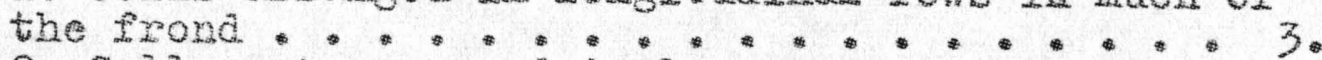
2. Cells not arranged in Longitudinal rows except at tines in the very youngest parts of the frond. - ... Enteronorpha intestinalis v clavata(2) 3. Fronds proliferous.... Enteromorpha prolifera(3)

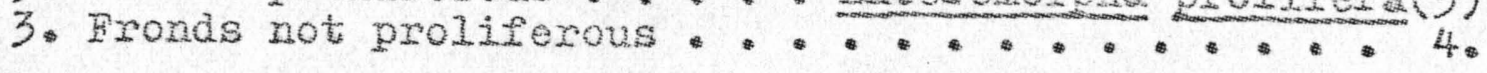


4. Fronds coarse, plainly tubular, of evident numerous longitudinal rows. Enteromorpha tubulose(4) 4. Fronds simple, inflated, and ilomous....

(1) Interomorphe 11nza (Limaeus) J. Agardh

Comnon throughout the Bay attached to rocks in the intertidal zone.

Setchell and Gardner (1920), p. 262.

Scagel (1966), p. 52.

collection numbers: $5,78,107,108,146$.

(2) Enteronorpha intestinalis $\mathrm{v}$, clavata J. Agardh onily June 29.

Setchell and Garduex (1920), p. 253.

Scagel $(3966)$, p. 50.

Collection mumber: 154 .

(3) Enteronoroha prolifera (Mulex) I. Agardh Fis. $8+9$ Attached to rooks ox sand at +1.0 to +3.0 , forming green mats over large areas of exposed sand, especially in the protected cove formed by the boat jetty. Present during the surnex months ony.

Setche11 and Gardner (1920), D. 254.

Collection numbers: $121,147,174$.

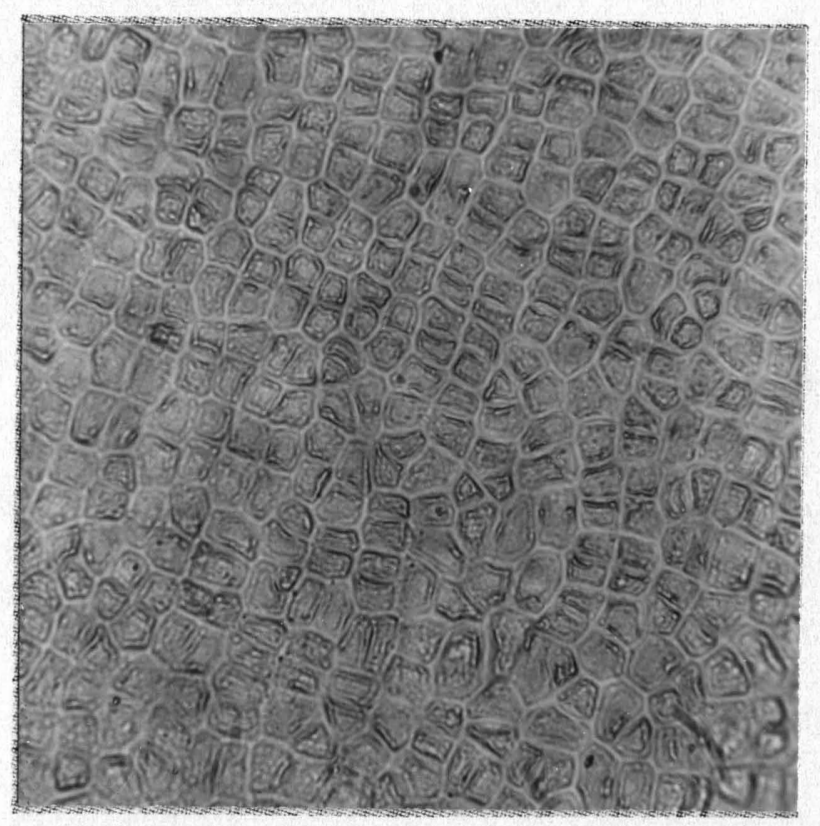

Rigute 8. Enteronomh. prolifere, showing a surface view of the vhatmus ( $40 \mathrm{~W})$ 


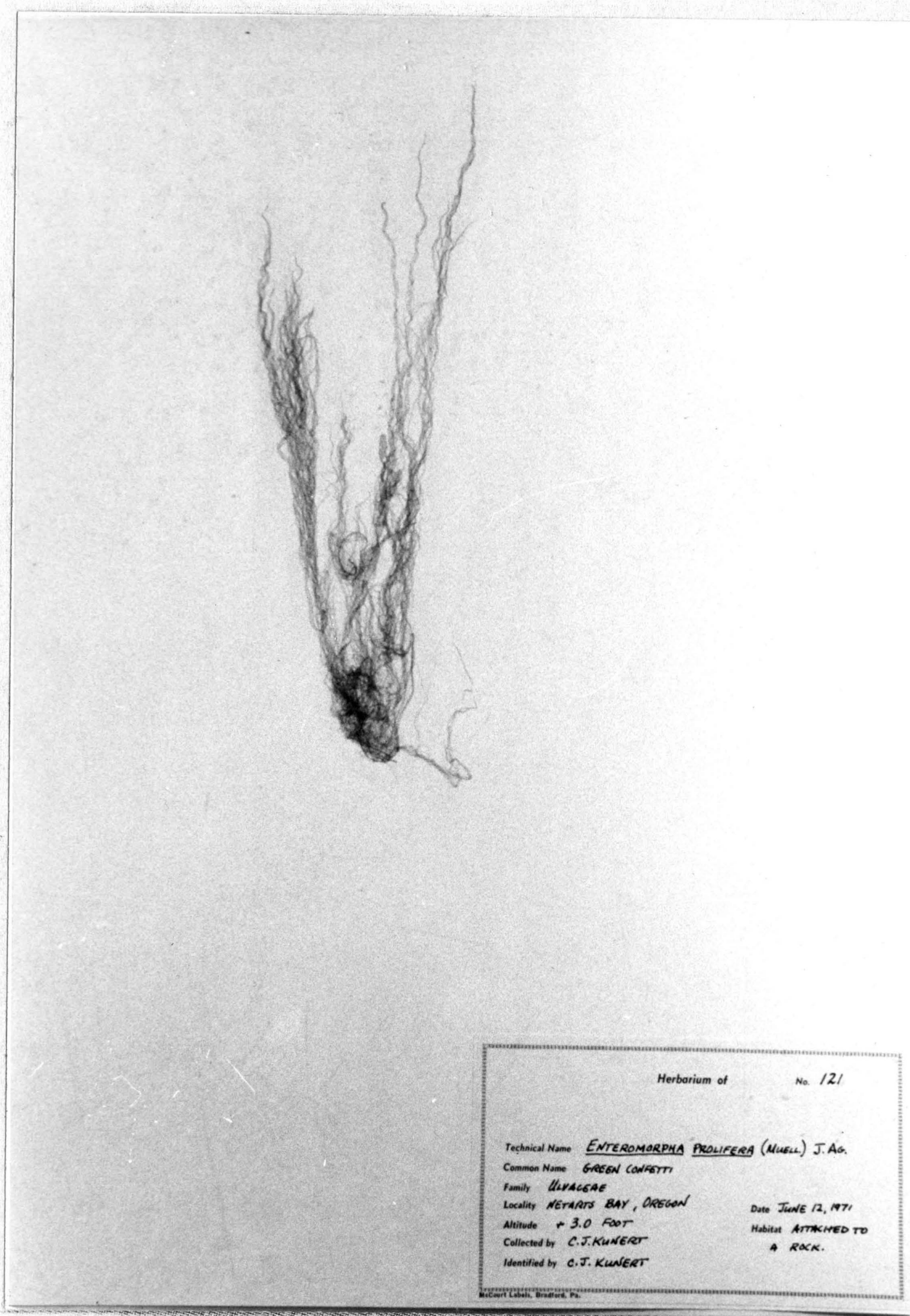

5igure 9. Enteronoroha prolifera: (1/x) 
(4) Enteromorpha tubulosa Kuetz. June 29. Attached to rocks $2 t-1.0^{\prime}$ in zone 3. Collected only Setchell and Gardner (1920), p. 256. Scagel, (1966), p. 56. Collection number: 155.

(5) Enteromorpha flexuosa (Wulf.) J. Agardh On rocks and logs of the intertidal zone. Setchell and Gardner (1920), p. 255. Collection number: 58,160 .

Ulva Thuret

\section{Key to the Species}

1. Cells square in cross section, frond uarrowly lanceolate . . . . . ....... Ulva angusta(1) 1. Cells rectangular in cross section . . . . 2 . 2. Frond broad in proportion to height..... 3 .

2. Frond narrow in proportion to height... 5 . 3. Frond with regular, abundant perforations . . . . ............. Ulva fenestrata(2) 3. Frond with a few irregular holes or none at all . 4. 4. Frond short, lanceolate to ovate, usually split deeply . . . . . . . . . Ulva rigida(3) 4. Frond large and expanded with ruffled edges.

5. Frond long, simple, and much ruffied lo expansa (4) ............ Ulra stenophylia (5) 5. Frond very short, simple, plane. - Ulve vexata (6) 5. Frond divided into long strips borne on a short, broad basal portion....... Ulva dactylifera(7)

(1) Ulva angusta Setehell and Gardner Fig. 10. Attached to rocks by a very short, solid stipe and a minute disc-shaped holdfast at $-1.0^{\prime}$ in zones 3 and 4. Very comon in places. Setchell and Gardner (1920), p. 264. Collection numbers: 53,158 .

(2) Ulva fenestrata Postels and Ruprecht Cormon throughout the Bay attached to rocks or

free-floating. Reaches lengths of more than 1 meter, and is very variable in shape.

At times this species is difficult to distinguish from Ulva expansa because of the arbitrary nature of the classification scheme. It may at times be difficult to decide whether holes are "regular" or not. Setchell and Gardner (1920), p. 267. Scagel (1966), p. 59 . Collection numbers: $26,54,88,123,153,189$. 


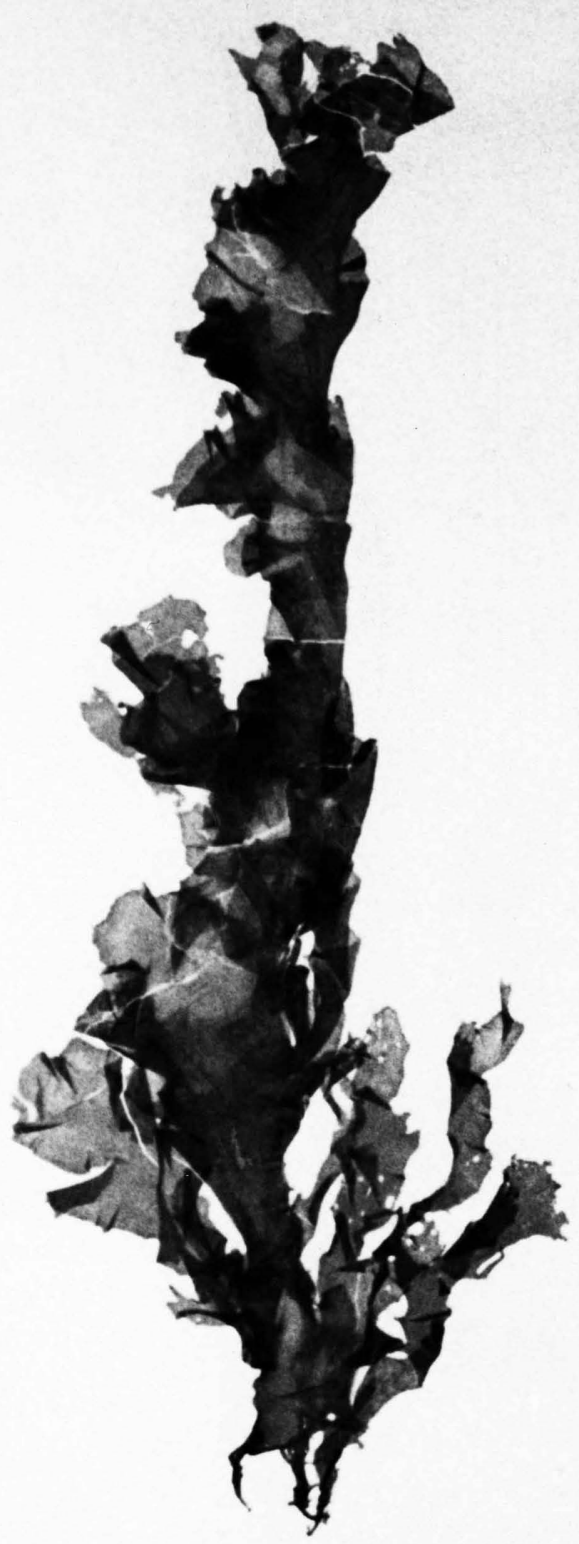

Herbarium of

No. 124

Technical Name ULWA AWGUSTA SETrNGLL ANO GARENGR Common Name SEA LETruce

family ULVACEAE

Locality NETHETS GAY, ORGGON

Altitude -2.0 foor

Collected by C.J. Kuncer

Itentitied by C.T.KuNERT

Date JUNE /2,197/

Habitst ATTACHED TO Rack

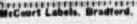

\section{Pigure 10. W17a angusta. (1/2)}




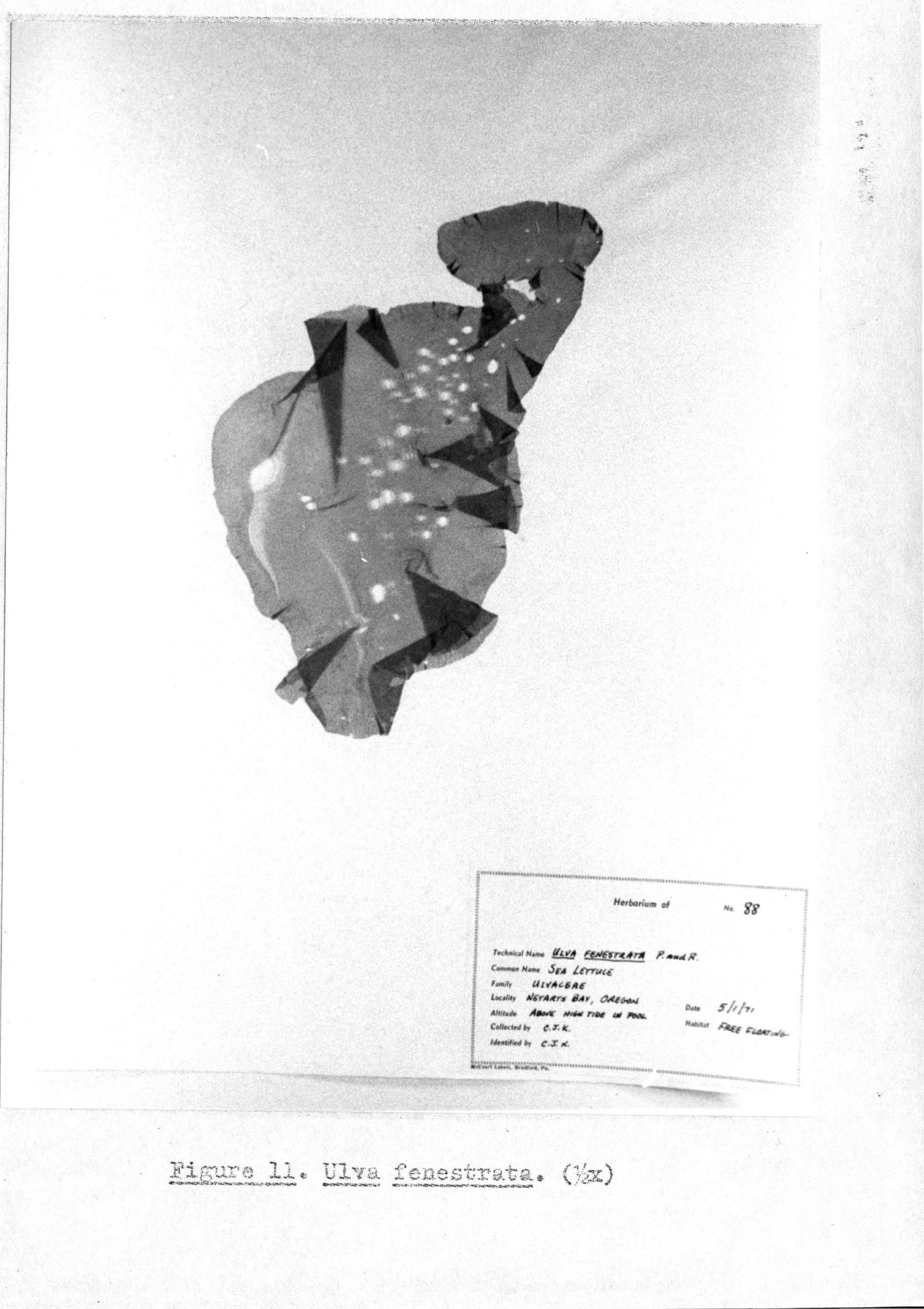


(3) Ulva rigida C. Agardh Attached to rocks from the sublittoral. Collected by Paul Bethke while skin-diving near the boat jetties. Collected March 13. Setchell and Gardner (1920), p. 269. Scagel (1966), p. 61. Collection number: 45 .

(4) UIva expansa (Setchell) Setchell and Gardner Attached to exposed mud or sand at low tide or free-floating. Not cormon. Setchell and Gardner (1920), p. 268. Scagel (1966), p. 58. Collection numbers: $36,69$.

(5) Ulva stenophylla Setchell and Gardner Very common attached to rocks in the high subtidal to low intertidal zone in zones 1 and 2 . Sone reaching 2 length of 1.5 meters. Setchell and Gardner (1920), p. 271. Collection numbers: $100,129$.

(6) UIva vexata Setchell and Gardner Isolated example found January 22 near the boat jotties on high intertidal rocks. Setchell and Gardner (1920), p. 271. Collection number: 1 .

(7) UIva dactylifera Setchell and Gardner At times abundant attached to rocks in the high intertidal zone near the boat jetties. Collected Maroh 13.

Setchell and Gardner (1920), p. 272.

Collection numbers: 39,40 .

\section{Order: Ulotrichales}

Ulothrix inplexa Kützing

On bridge pilings, forming a bright green layer. Collected February 20.

Setchell and Gardner (1920), p. 283.

Scagel (1966), p. 28.

Collection number: 30 . 


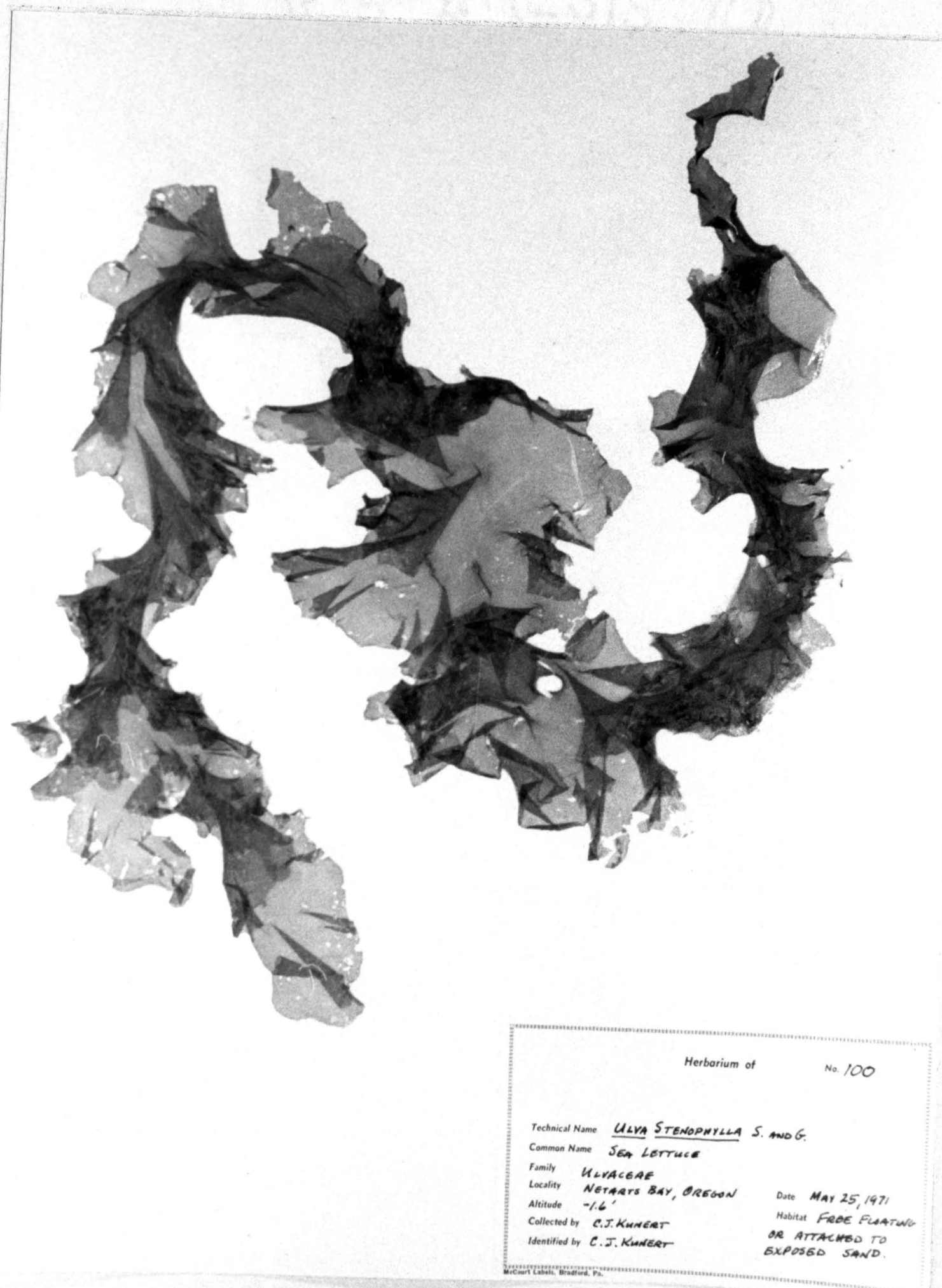

Djgure 12. U17a stenophy112. $(1 / 2 x)$ 
II. DIVISION: PHAEOPHYMA

Class: Isogeneratze

order: Ectocarpales

Betocarpus Lyngbye

Key to the Spocies

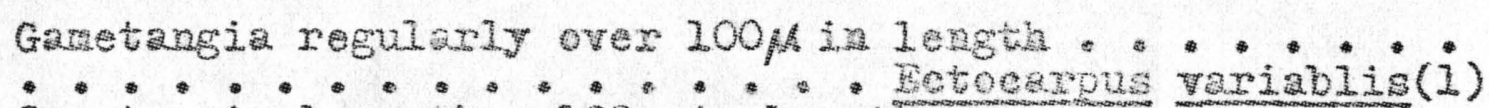
Ganetangia less than $100 \mu$ in length ... -... Ectocaxpus conferrojdes v confervoides(2)

(1) Ectocaxpus varjablis (Saunders) G. M. Smith

Epiphytic on Zostera. collected June 29. Higss. $13+14$. Setchell and Garoner, $(1920), 2.413$. Stith, $(1944), p \cdot 85$.

collection nuber: 163.

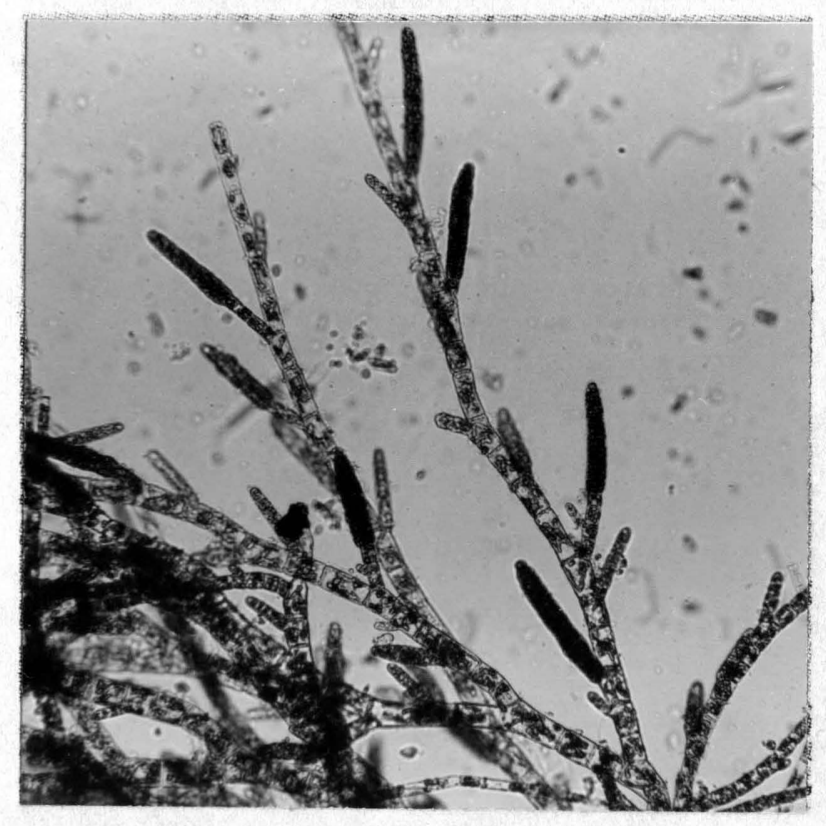

Figure 13. Fotocangus variablis, showing branchine

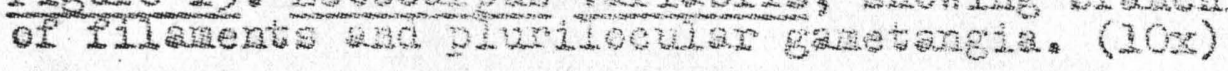

(2) Ectocarpus conferrojdes $\mathrm{v}$. gonfervojdes (Roth) LeJolis Epiphytic on Zostera and Desmerestia. 


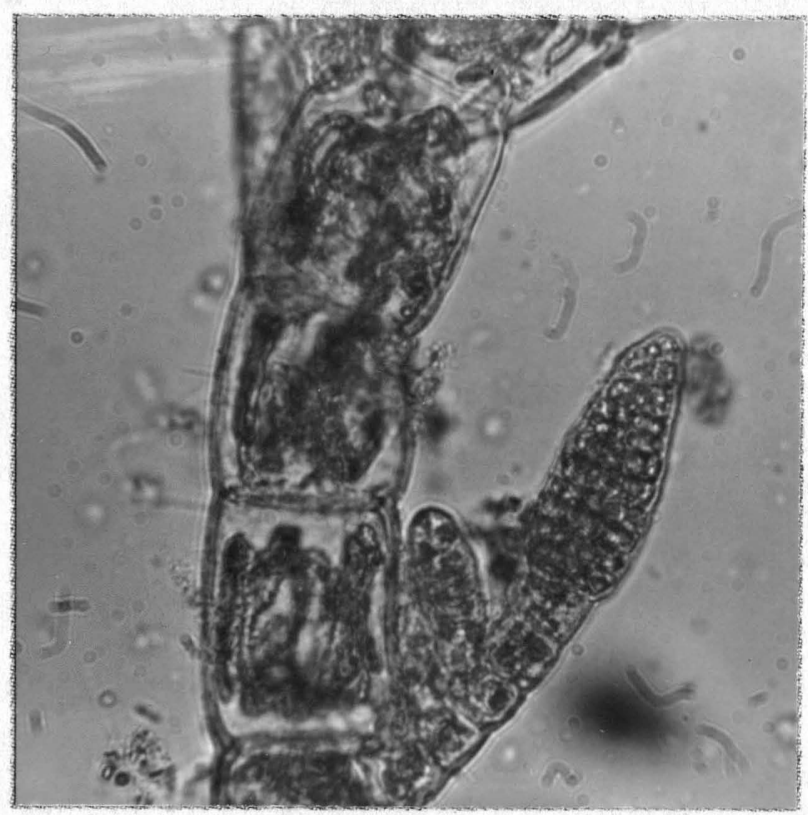

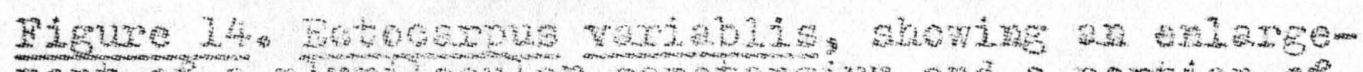

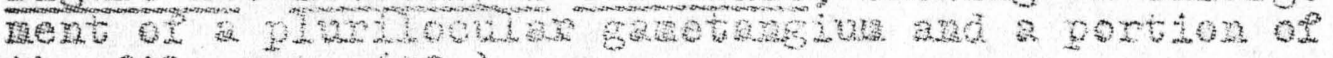
the filarents. (40x)

Setchell and Gryaner (1920), $\mathrm{p}, 4 \mathrm{~L}$. Scagel (1957),, 68.

Collection numbers: $109,179$.

\section{Gass: Hevorogeneratae}

\section{Order: Punctariales}

Phaeostrophion irregulare Sotohell and Gardnex

Comizon in zones I and 3 on roeks at $-0.5 \%$ Usually in bunches, and rarely exceeding 4 cm in heighth.

Setchell and Gardner (1920), p. 586.

Hollenberg and Abbott (1966), $\mathrm{p} .23$.

Collection nuaber: 172 .

\section{Order: Dearerestivies}

Desnerestia Ianouroux

$$
\text { Key to the Species }
$$

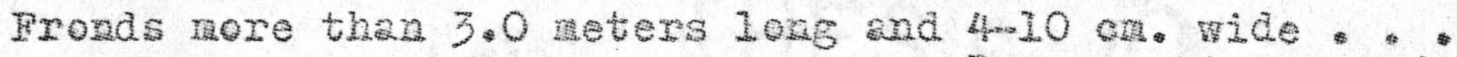
Fronds less than 10 neter iong and $\frac{\text { Desnerestia }}{1-2}$ munda(1) Fronds less than 1.0 meter long and $1-2$ cm nide.$\dot{D} \cdot(2)$ 


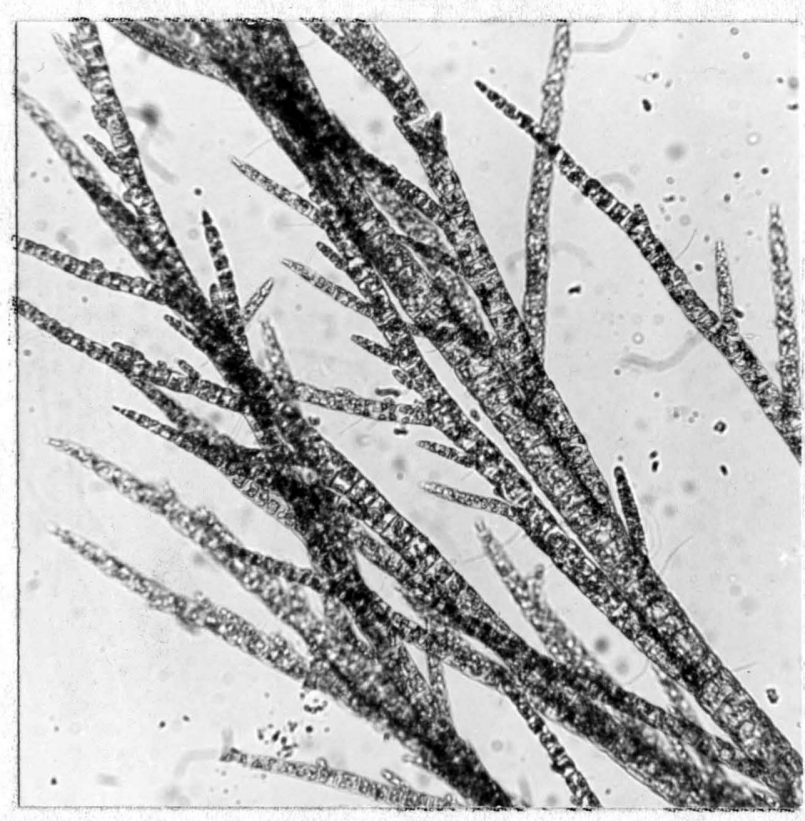

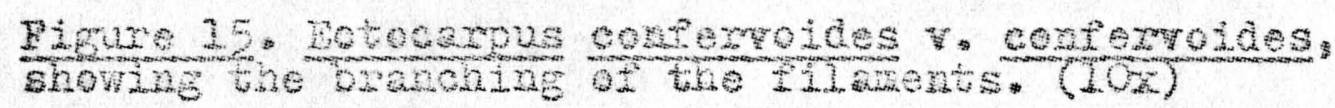

(1) Desrexestia munda Setrohel1 and Gardner Common throughout the Bay, atrohed to rocks and shells, but especially frequent in zones at the northeast edse of the Bay.

Setche 11 and Garduer $(1920), p .567$.

Srath, $(1944), \mathrm{p} \cdot 121$

Collection numbers: $110,122$.

(2) Desmerestia herbacea (Turner) Ianouroux

Fig. 27.

Rare attached to rocks at $-3.0^{\prime}$.

Setche11 and Gardner (1920), p. 566.

Smith $(1944), D \cdot 121$.

Colloction numbers: $104,204$.

\section{Order: Laminariales}

Iaminaria Saccharins T. Saccharina (Linnacus) Lamouroux Comon attreked to zocks at -1.0 to $-4.0^{\prime}$. Sazo fronds have evident bullations, while others lack then entirely. To a length of 3.0 meters. Setchell and Gardnex (1920), D. 595. Scage1 (1957) * p. 97. Collection numbers: $95,101,116,125$. 


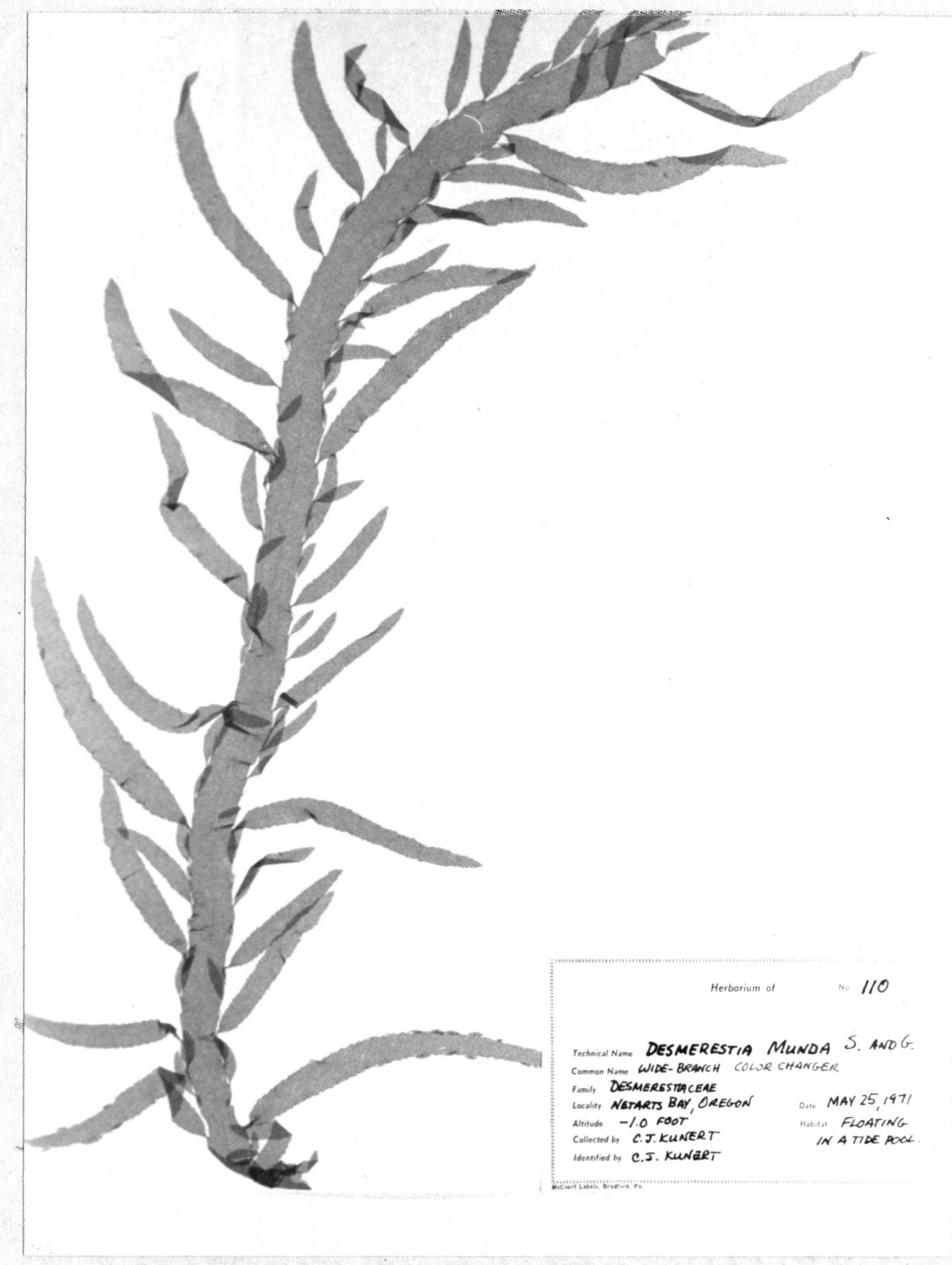

Higure 26* Desnerestia munda. ( $/ 2 x)$ 


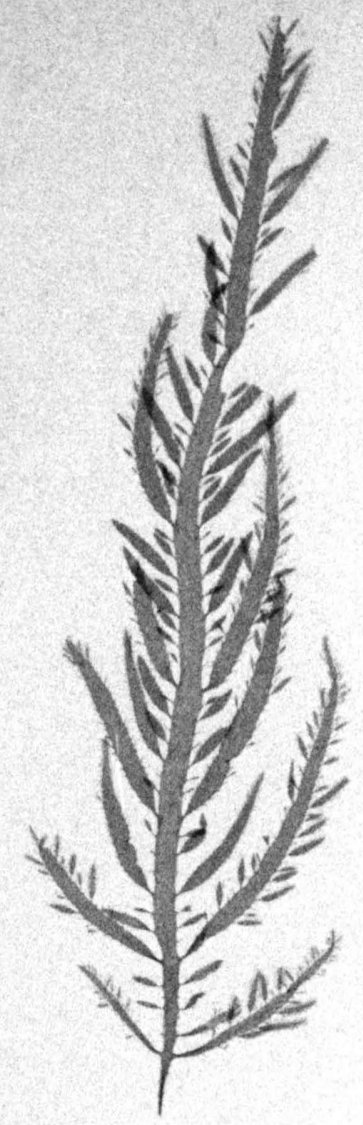

Herborium of

Technical Name DESMERESTIA HERBACEAR (TweVER) LAw Common Name WIAT-BRANHED COLDR CHANGER

Family DESMERESTIA CEAE

Locality NeTARTS BAY, OREGON

Altitude $-3.0^{\prime}$

Collected by C.J. KuneRT

Identified by C.T.KunereT

Dote JuLY /2, 197,

Habitut ATTACHED

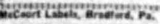

Digure 2? Decuerestia hexbacea. (1/2x) 


\section{Class: Cyclosporeae}

\section{Order: Fucales}

Sergassun muticum (Yendo) Fensholt Extremely common along the east shore of the Bay fron -1.0 to $-20^{\prime}$. To a length of 3 meters. Scagel (1967), p. 164.

Collection numbers: $41,44,76,106$.

Fucus gardneri v. abbreviatus (Gardner) Scagel

4 and 5 . very common at +1.0 to $+3.0^{\prime}$ in mudflats of zones Setchell and Gardner (1920), p. 672. Scagel (1957), p. 116. Collection numbers: 56,81 .

\section{DIVISION: RHODOPHYTA}

\section{Class: Rhodephycere}

\section{Order: Bangiales}

Bangia vernicularis Harves Forning a thin green to rusty brown scum on high intertidal rocks. Thalli increasing in size as the jear progresses. To $1 \mathrm{~cm}$. during Pebruary and up to $5 \mathrm{cn}$. during June.

Smith (1944), p. 167.

Collection numbers: $23,149,150$.

Smithora naiadun (Anderson) Hollenberg Frequently occuring and epiphytic on Zostera and

Phyllospadix. Collected June 29 and July 9. Snith (1944), p. 169 .

Hollenber and Abbott (1966), p. 37.

Scagel (1957), p. 129.

Collection numbers: $163,188$.

Porphyra C. A. Agardh

\section{Key to the Species}

Frond mucn expanded, of irregular shape • • • • • Frond inear-lanceolate in shape - Porphrra $\frac{\text { perforata }}{\text { anceolata }}$ (2)

(1) Porphyra perforata J. G. Agardh

Comon throughout the range attached to rocks, sand, or free-floating, but especially comon in zones 5 and 6 . 


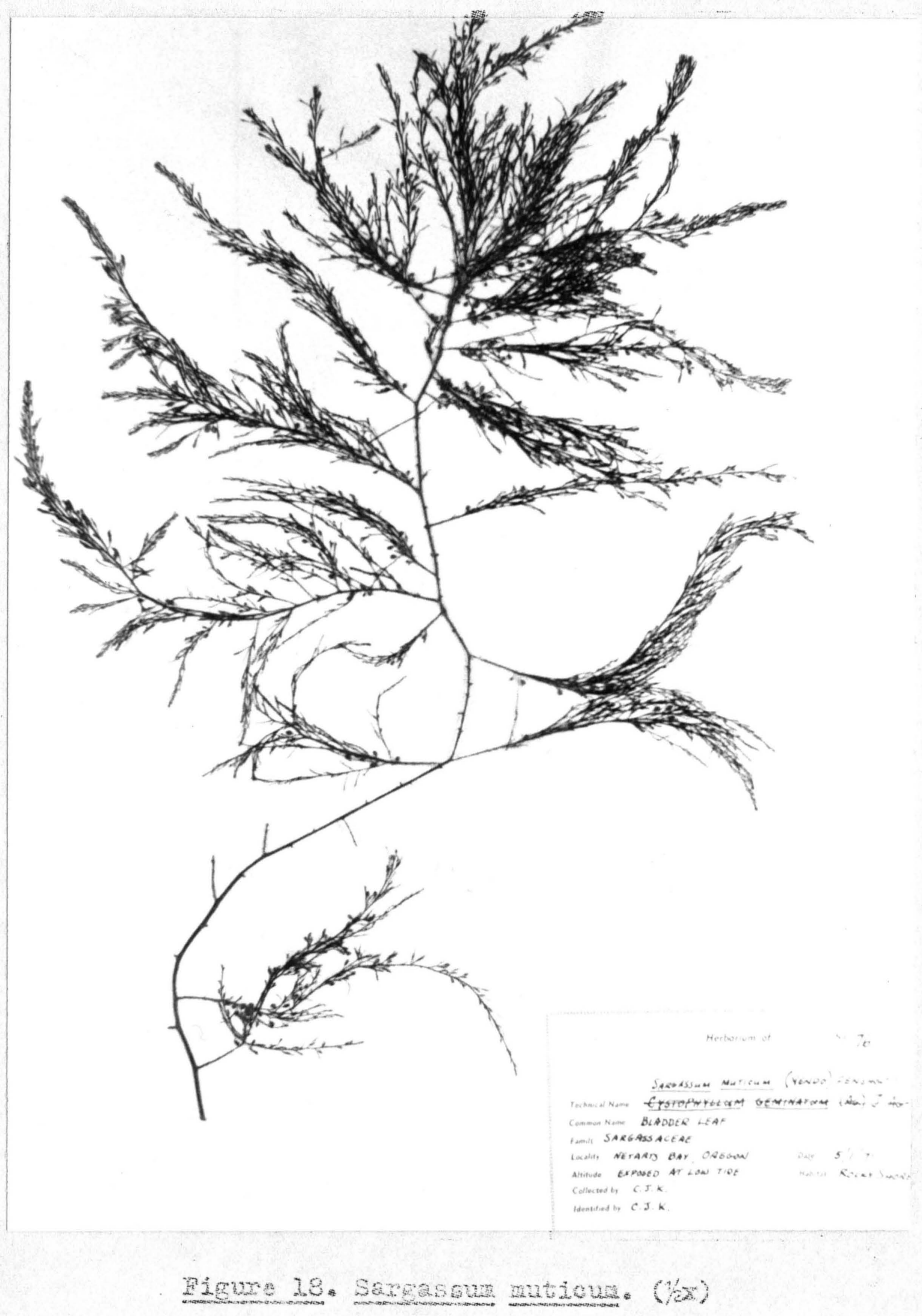




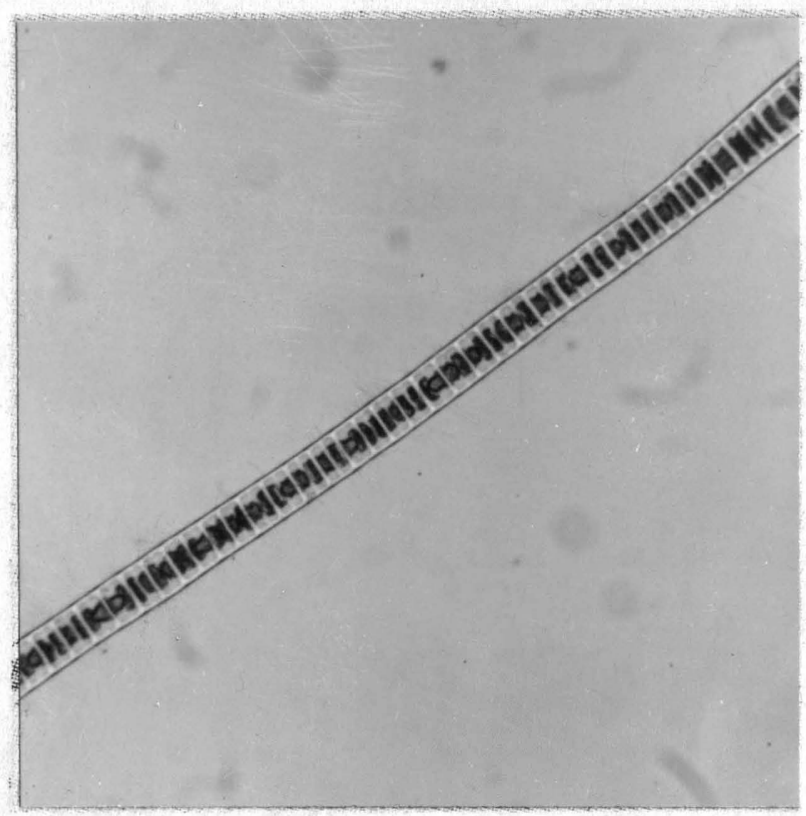

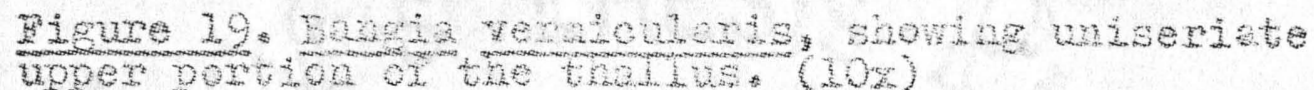

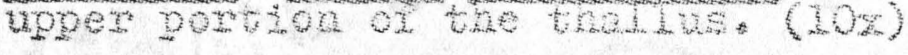

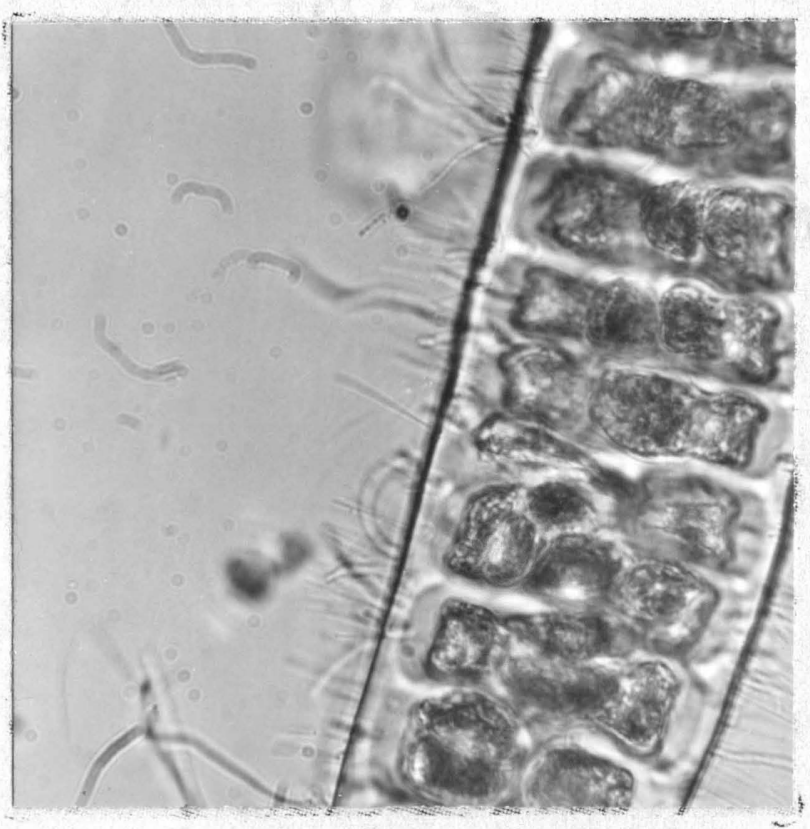

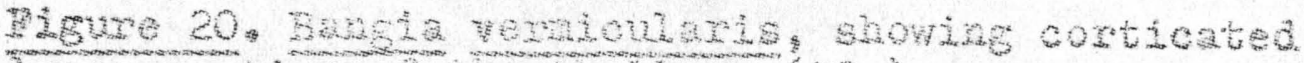

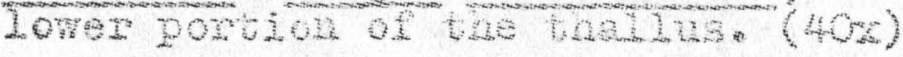

Snith $(1944): P * 272$

Collection numbers: 3es 70, 77. 


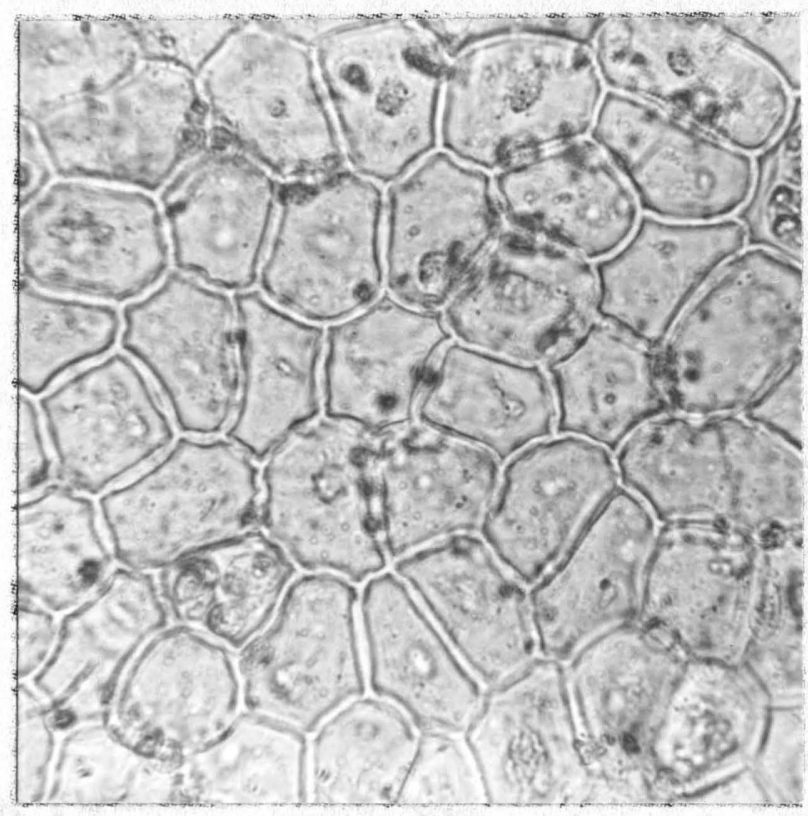

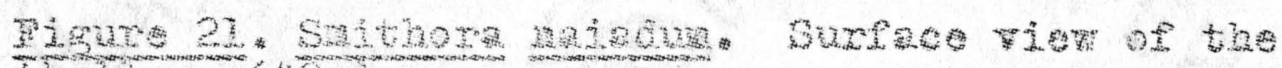
that IU: $(40 x)$

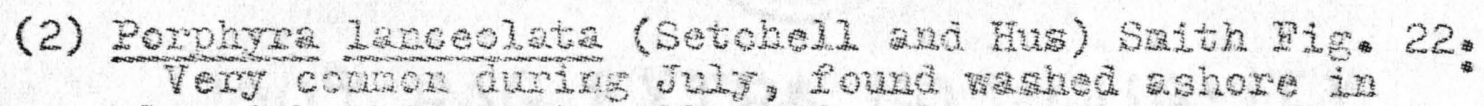

zone 1. Othermise not collected. Sone take on very bright red to rea-trange coloration.

Shith (1944), p. 170

Collection number: 186.

\section{Order: Cryptoneralas}

Cryptosiphonia woodij J. G. Agardh

Iis. 23. Conmon througrout the Bay on rocks and logs in the low intertidal to high littoral zones. Srith (1944), p. 200. Collection rubers: $6,29,35,131,140,168$.

Lithotharnion eslifornicun Fosie Comon during sunter months on rocks at -2.0 to $-4.0^{\prime}$, forming a thick whitish-pink caloareous lager. Snith $(1944)$, p. 221. Collection number 199.

Dermatolithon dispar (Fosize) Foslis

Cornon epiphytic on Ahneltia, forming a calcareous tube which surrounds pamy of the branches.

Snith (1944), p. 225.

Hollenbers and Abbott (1966), p. 61.

Collection number: 187 . 

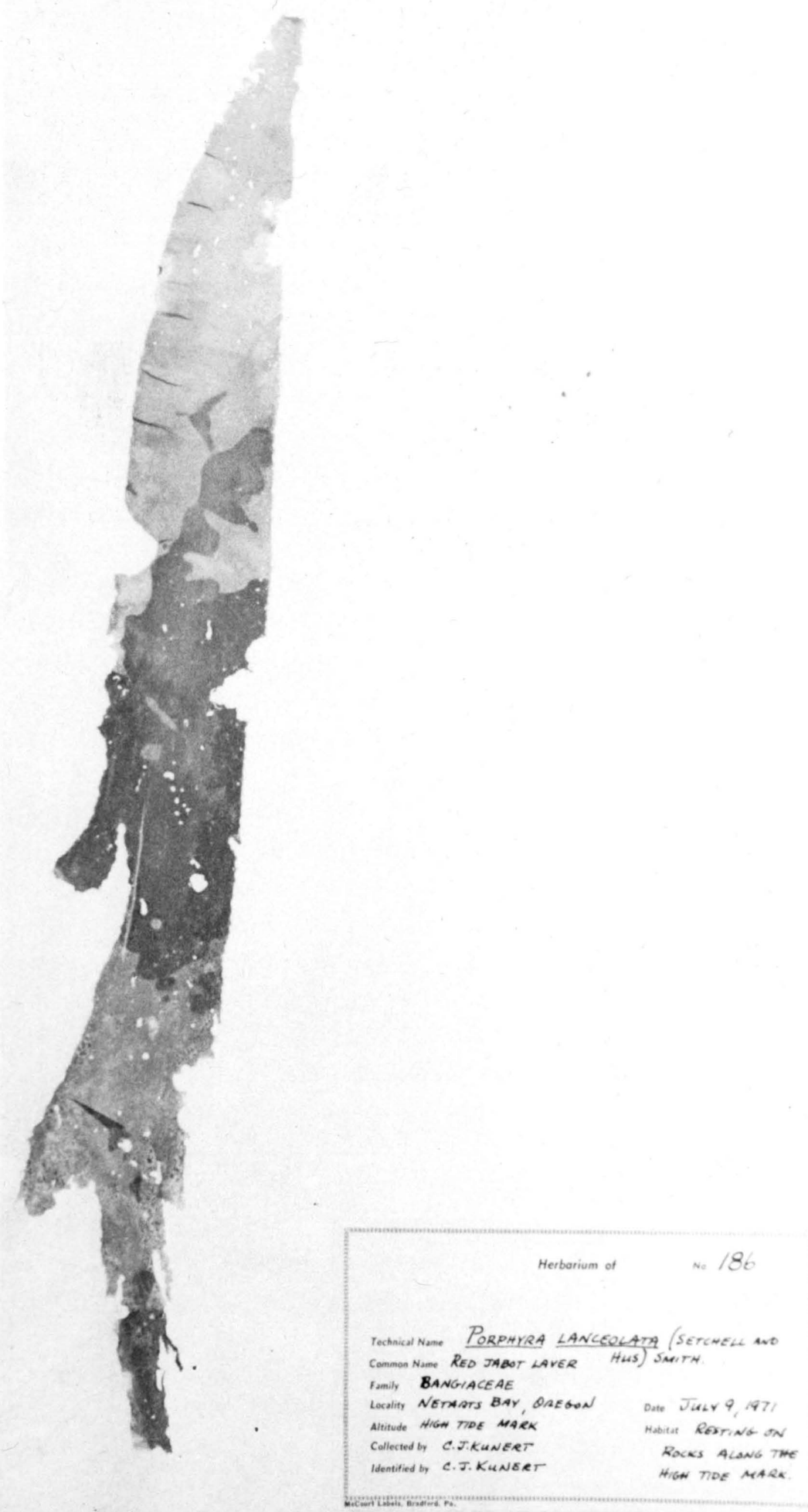

Tigure 22. Porphyma Lanceolata. (1/x) 


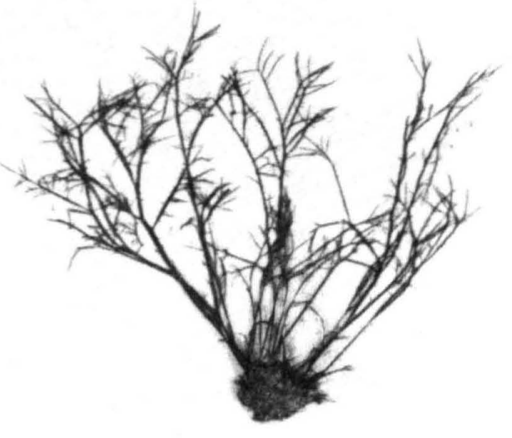

Herbarium of

Na 35

Technical Name Cryptosipnonia

Wood

J $6, A 6440$

Family DUMONTIACEAE

Locality NETARTS BAV, OREGON Date FEB.20,197,

Altitude +1.0 foor

Habitst ON LOGS in

Collected by C.J.KUNERT TIOE FLATS

Identified by C.J. KUNERT

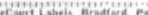

Bigure 23. Gryptosiphonia woodil. (1/2x) 
Corallina officinalis v. chilensis (Harvey) Kützing OnIy one specined collected. Very few coralline algae are to be found in the quiet waters of Netarts

Bay. Collected July 9. Smith (1944), p. 230. Scagel (1957), p. 156.

Collection number: 191.

Prionitis J. G. Agardh

$$
\text { KeJ to the Species }
$$

Branches 2.5-5 ma. broad, linear. Prionitis lanceolata(1) Branches to $20 \mathrm{mr}$. broad, lanceolate ${ }^{\circ} \cdot \dot{C}^{\circ}$ (i)

(1) Prionitis lanceolata Harvey 30 . An isolated specinen cast ashore. Collected June Smith (1944), p. 246. Collection number: 176.

(2) Prionitis andersonii Eaton to 3.0 '. Common in zones 1 and 2 attached to rocks at $-i .0$ Smith (1944), p. 246. Cellection number: $111,135,200$.

Cellophyllis oregona Doty Infrequent on rocks in the intertidal to littoral zones. All specimens sterile. Doty (1947), p. 175 . Collection numbers: $117,196$.

\section{Order: Gigartinales}

Plecanium coccineum $r$ pacificun ( $K_{j} l i n$ ) Dawson CoIlected from algae cast ashore in zones 1 and 6 . Collected only June 30 and July 9. Swith (1944), p. 264. Dawson (1961a), p. 264. Hollenbers and Abbott (1966), p. 85. Collection nubers: 175,185 .

Gracilariopsis sjoestedtii (KJIin) Dawson Fig. 25. Conmon throughout the Bay attached to rocks at -1.0 to -3.0 ', or, at times, growing much higher up on nud.

Snith (1944), p. 267.

Scagel (1957), p. 181 .

Collection numbers: $8,82,113,114,115,128$. 

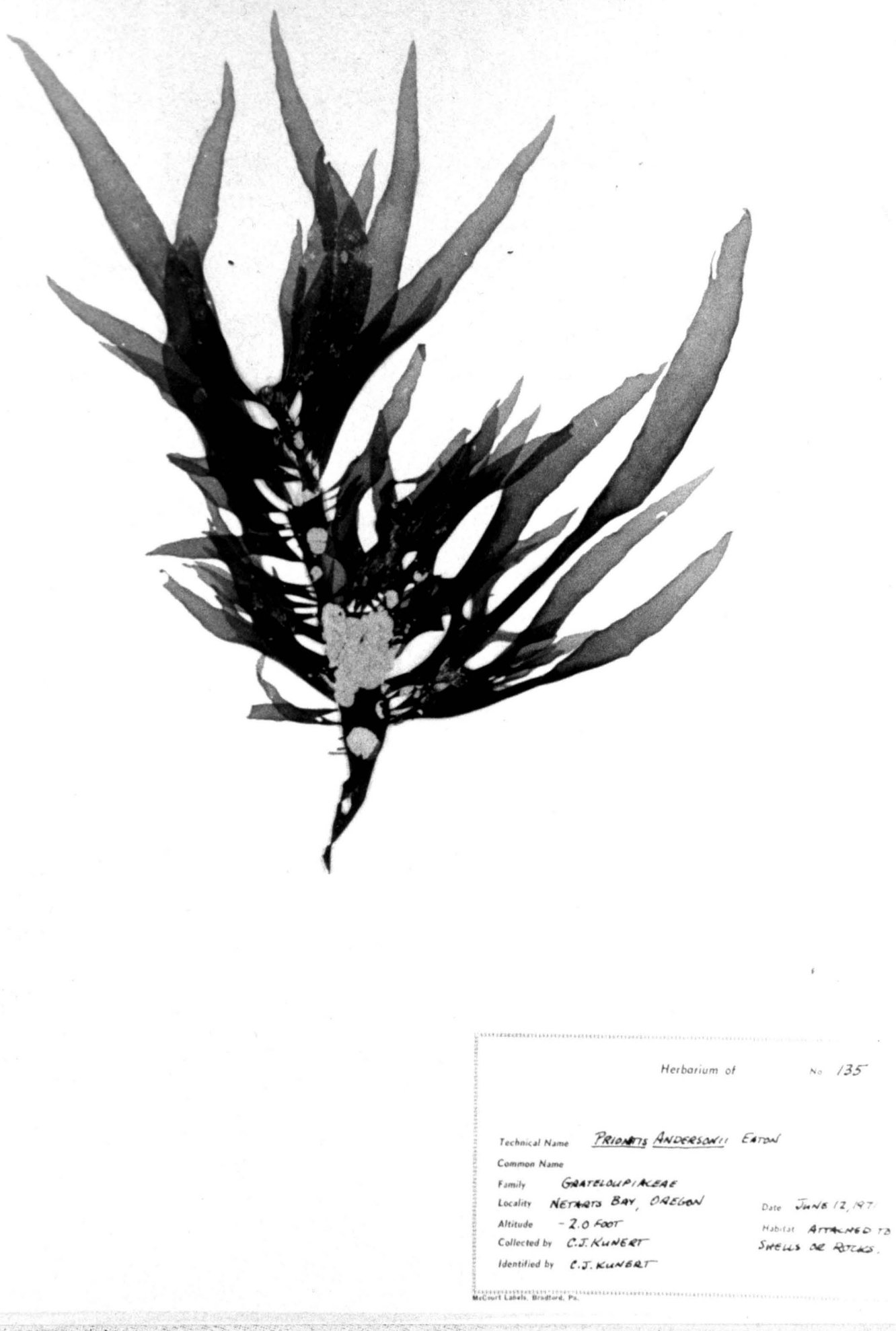

Pigure 24: Prionitis andersoni1. ( $/ 2 x)$ 


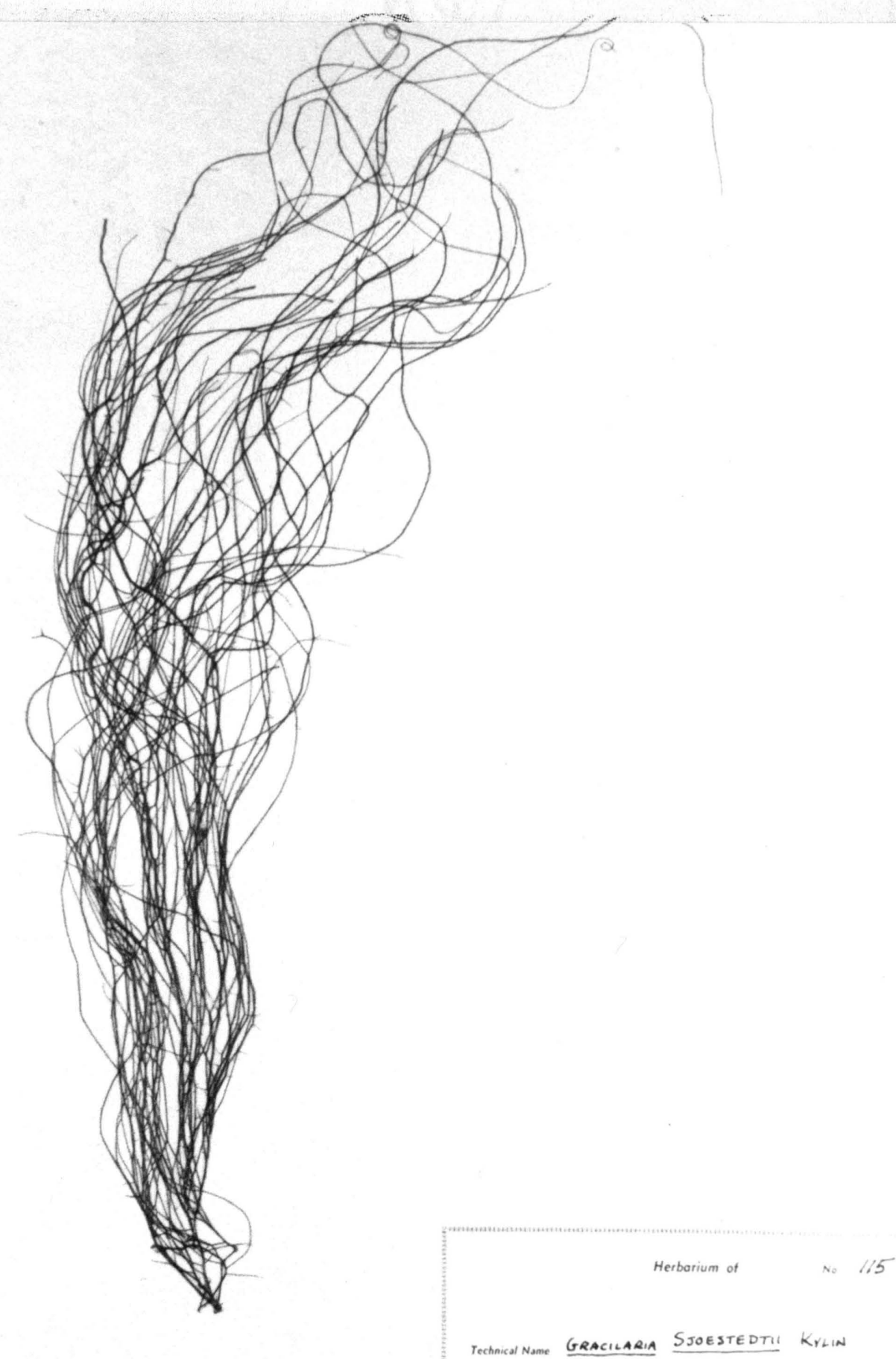

Technical Name GRACILARIA SJOE

Family GRACILARIACEAE

Locality NETARTS BAY OREGON

Altitude -1.0 foor

Alinde -1.0 RoOT

Oate MAY 25, 97

$\begin{array}{ll}\text { Collected by } & \text { C.I. KUNERT } \\ \text { Identified by } & \text { C.J. KUNERT }\end{array}$

Habitat ON ROCK

BONE.

\section{Pigure 25. Gracilariopsis sjoestedtii. (1/2r)}


Ahnfeltia Fries

Key to the Species

Branches less than $0.5 \mathrm{~mm}$. in dianeter $\cdot \bullet^{\circ} \cdot \dot{p}_{i} \cdot{ }_{i}$ Branches $0.5^{\circ}$ to $\dot{1} . \dot{0}$ in. in diareter ....................... Anfia concinna(2)

(1) Alnfeltia plicata (Hudson) Fries Very common on rocks at -2.0 to $-4.0^{\prime}$ in zones 1

and 2. Forming very dease tufts of wiry branches. Srith (1944), p. 271.

Gollection numbers: $133,187$.

(2) Ahnfeltia concinna (J. G. Agardh) Setchell and Gardner Rare on rocks and shells in the intertidal zone. Srith (1944), p. 272 .

Soagel (1957), p. 182 .

Collection numbers: $119,198$.

Gymogongrus leptophyllus J.G. Agardh

Very conmon on the surface of the shoreline in

zones 4 and 5 where only very high tide would reach.

Smith (1944), p. 273.

Collection number: 79.

Gigartina Stackhouse

Key to the Species

1. Blade with an evident thickened ridge along the margin

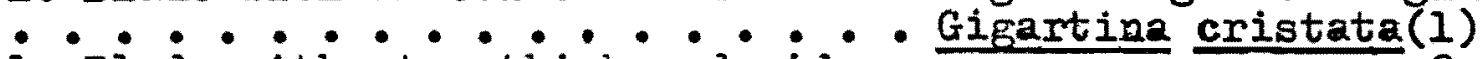

1. Blade without a thickened ridge $\cdot \bullet^{\prime} \cdot \bullet_{\bullet} \cdot 2$.

2. Papillae distinctly flattened $\cdot 0^{\cdot} \cdot \bullet^{*} \cdot \dot{ }^{\circ}$

- • • • • • • • • - Gigartina volans(2)

2. Papiliae acutely pointed or rounded . . 3 .

3. Blade relatively broad, subdichotonously divided.

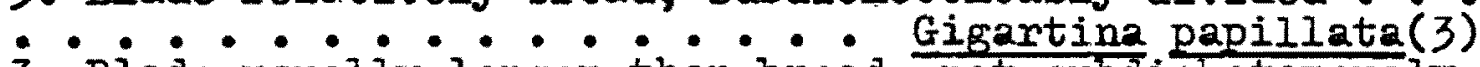

3. Blade usualiy longer than broad, not subâichotomousiy

divided . . . . . . . . . . . . . 4.

4. Blades linear-lanceolate and once or twice dichotomously divided from a stipitate lower portion

*... * - * Gigartina harreyana (4)

4. Blades usualiy simple, obovate-lanceolate $\cdot 5$.

5. Apex of blade tapering to an acute point $\ldots$

- - - * - - - - - Gigartina celifornica (5)

5. Apex of blade generally rounded. 
(1) Gigartina cristata (Setchell) Setchell and Gardner Rare attached to rocks at the $-1.0^{\prime}$ mark. In tufts

from a comon discoid holdfast. Dark brown to red in

color when fresh.

Smith (1944), p. 283.

Collection numbers: $22,137$.

(2) Gigartina volans (C. A. Agardh) J. G. Agardh Fig. 26. Rare in the Iow intertidal zone on rocks. Dark red-

brown in color. Blades smooth compared to other Gigar-

tina. (Identified by Dr. Isabella Abbott.)

Smith (1944), p. 282.

collection nurabers: $27,33,145$.

(3) Gigartina papillata (C. A. Agardh) J. G. Agardh

Fig. 27.

Common attached to the vertical faces of rocks at +1.01 . Edges of the blades are thickened. Dark brown in color.

Srith (1944), p. 283.

Collection nunber: 208.

(4) Gigartina harreyana (Kützing) Setchell and Gardner Common attached to rocks between -1.0 and $-3.0 \% 28$. Dull brownish-red color. To a length of $i$ meter. Smith (1944), p. 282.

Collection number: 134 .

(5) Gigartina californica J. G. Agardh Infrequent on rocks at $-1.0 \%$. Yellowish-brown in color. To 2 height of $25 \mathrm{~cm}$. Smith (1944), p. 280 . Collection numbers: 162, 182.

(6) Gisartina exasperata Harvey and Bailey Fig. 30. Throughout the Bay attached to rocks or more frequently attached to sand at $-1.0 \%$. Iridescent reddishgreen in color.

Scagel (1957), p. 185.

Collection numbers: 4, 34, 37, 90, 97 .

Rhodoglossum affine (Harvey) Kylin

Rare on rocks in the low intertidal zone. Collected February 20 .

Smith (1944), p. 287.

Collection number: 28. 

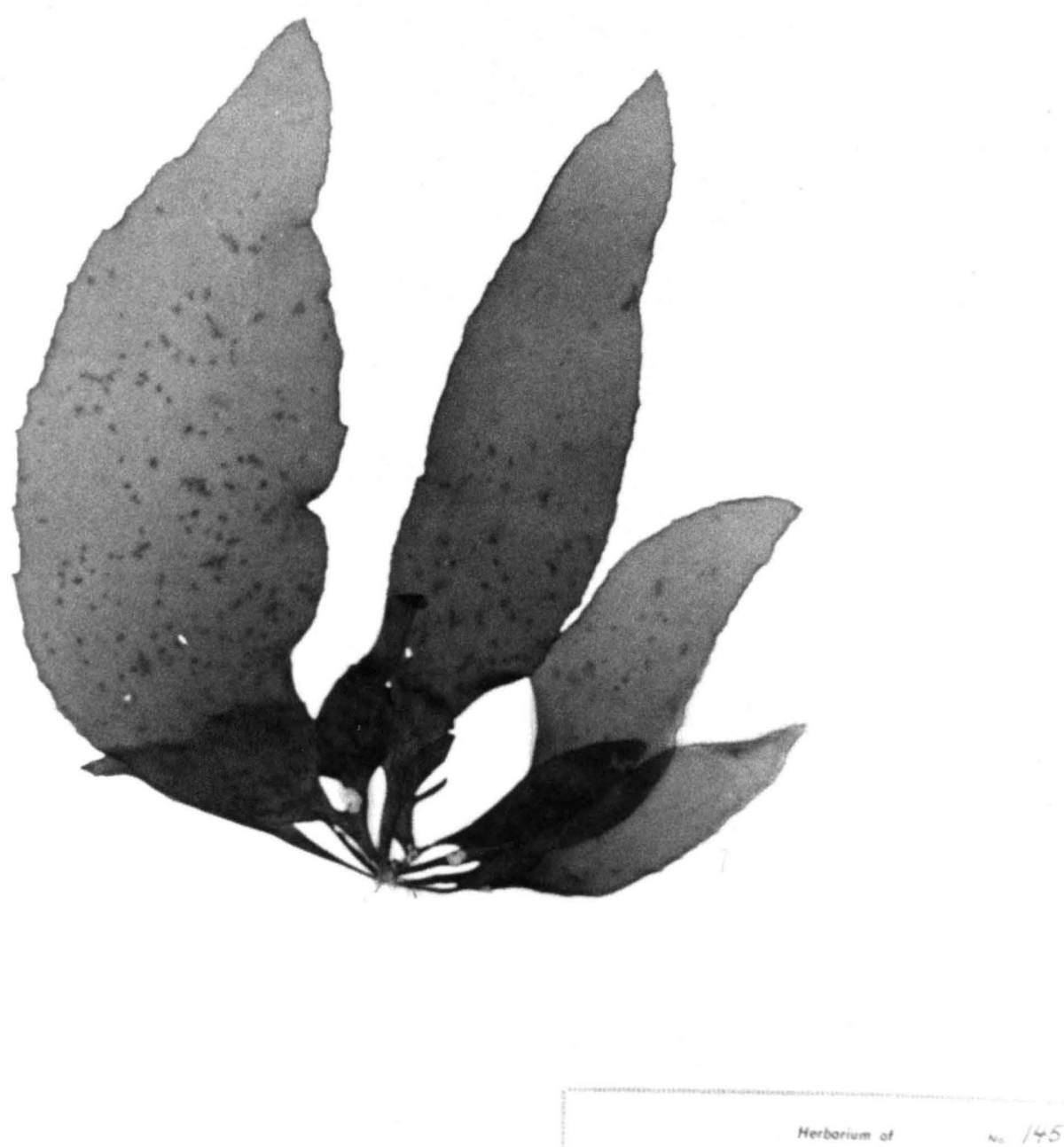

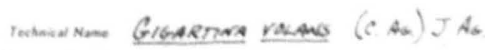

$$
\begin{aligned}
& \text { Commen N- TaAkisa rowe. }
\end{aligned}
$$

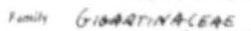

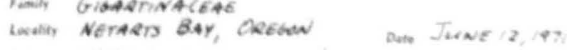

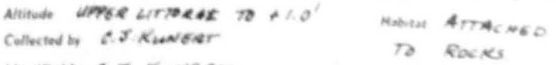

$$
\begin{aligned}
& \text { ideation on C.J. Kune er }
\end{aligned}
$$

Higure 26. G1gartina voluns. (1/2x) 


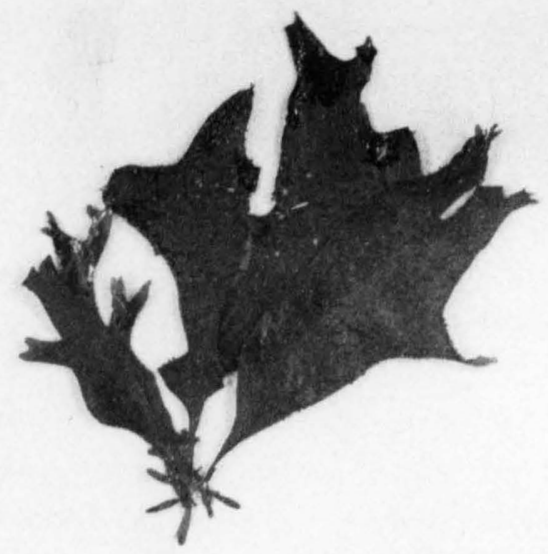

Herbarium of Na. 208

Techaical Name GIGARTINA PMPILLATA (C.AG) J.AG

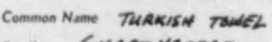

Family Grotennacede

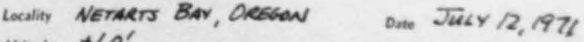

Altitude $\$ 1.0^{\prime}$

Habitat ATTACHED TO

Collected by C.J.Kunerer TWE VERTIAC

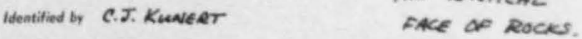




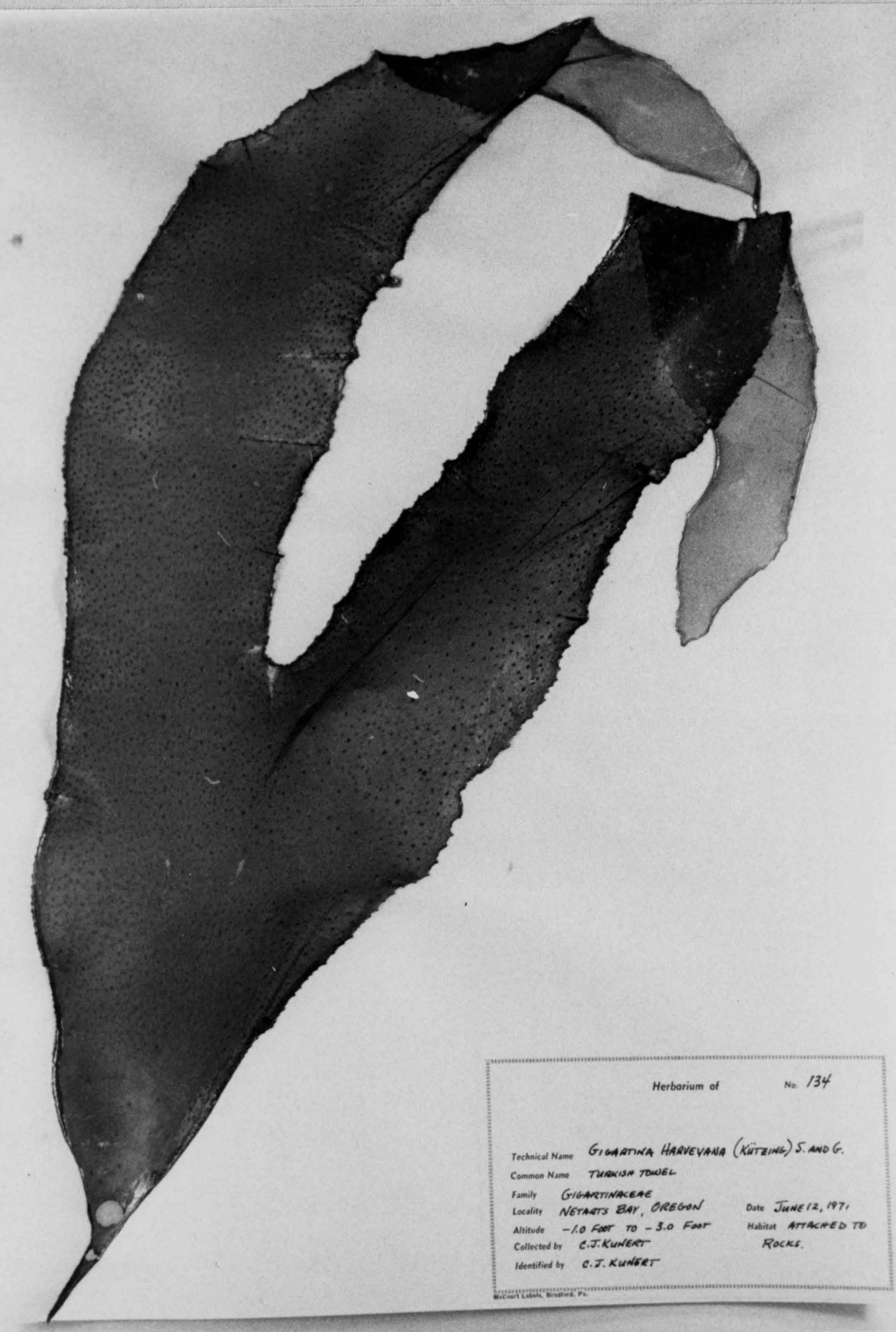

Figure 28. Gigarina harveyana. (1/2x) 


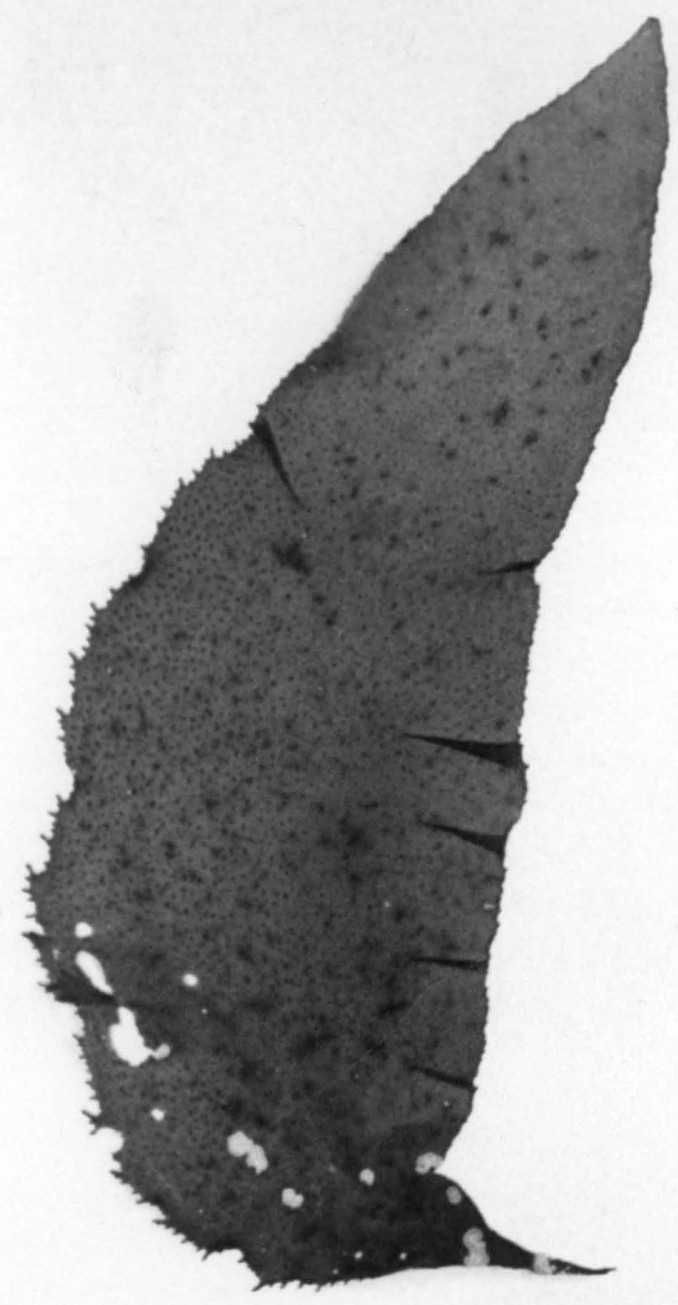

Herbarium of

\section{Technical Name}

Gigartina californica J.G. Agared

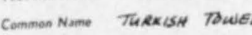

fumily GIGARENACGAE
Locality NETARTS BAY OREGON

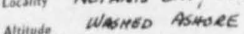

WASTED ASULEE

Date JuLY 9,197

Collected by C.J. KUNGeT

Habitat ATTACAES 


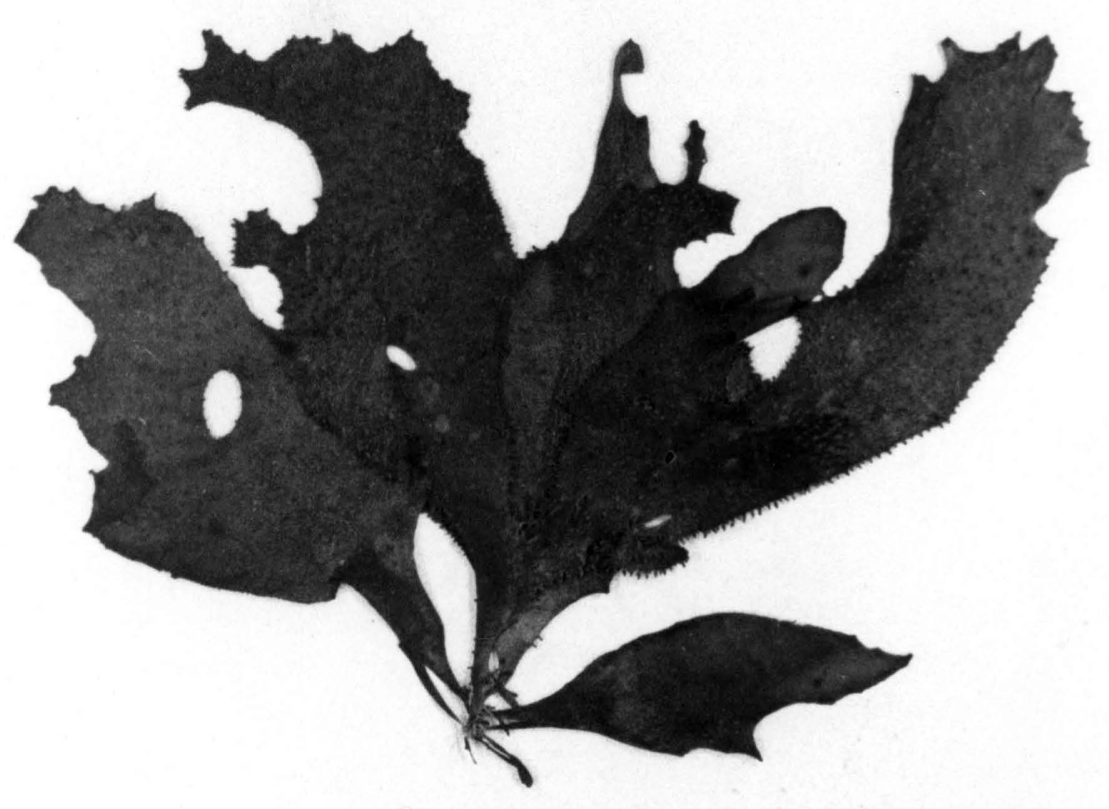

Herbarium of

Technical Name GIGARTINA EXASPERATA HARVEY BAnEY Common Name TURK/S H TOWEL

Family GigaRTinaceate

Locality NETARTS BAY, OREOON

Altitude +0.2 Foor

Collected by C.J.Kuneet

Dute FEB. 20,197 Mabitat ATtacuted 70

Identified by C.J. KunEaT Muck in troe

Rigure $30 \cdot$ Giestina exasperata. (1/2x) 
Iridaea Bory

Key to the Speoies

1. Blade deeply and regularly divided

- * - - - . - - Iridaea heterocarpa (1)

1. Blade not deepiy and regularly divided . . 2 . 2. Blade usually linear, more than 8 times as long

as broad ......... Iridaea Iineare (2)

2. Blade relatively broad....

3. Blade with a cordate base, more than twice as long as

it is broad . . . . . . . Iridzea cordata (3)

3. Blade usualiy broader than long . Iridaea whidbeyana (4)

(1) Iridaea heterocarpa Postels and Ruprecht Fig. 31. Rare attached to rocks at $-1.5 \%$ Thick and leathery in texture. Collected July 12 in zone 2.

Smith (1944), p. 291.

Scagel (1957), p. 191 .

Collection number: 201.

(2) Iridaea lineare (Setchell and Gardner) $\mathrm{Kylin}$ Rare attached to rocks at $-1.0^{\prime}$. Blade is usually spirally twisted. Collected June 12 in zone 2. Smith (1944), p. 290 .

Scagel (1967), p. 256.

collection number: 138 .

(3) Iridaea cordata (Turner) Bory

Fig. 32. Infrequent attached by a short holdfast to rocks $2 t$ -1.0 to -3.01 . Brightly iridescent in the water, but a dull brownish-green out of the water. Usually in groups of four or fire. Collected in zones 1,2 , and 3.

Smith (1944), p. 288.

Scagel (1957), p. 190.

Collection numbers: $136,167,183$.

(4) Iridaea whidberana (Setchell and Gardner) Scagel Fig. 33.

Infrequent on rocks $2 t-3.0^{\prime}$, usually in bunches. Blades reaching very large proportions, some upwards of 1.5 meters in length and width. Collected in zone 2. Setchell and Gardner (1937), p. 174.

Scagel (1957), p. 191 .

Collection numbers: $141,206$.

\section{Order: Ceramiales}

Antithamaion bylinii Gardner

Collected from a tidepool in zone 1 where it had been evidently washed from greater depths. Collected July 9.

Smith (1944), p. 307 . 


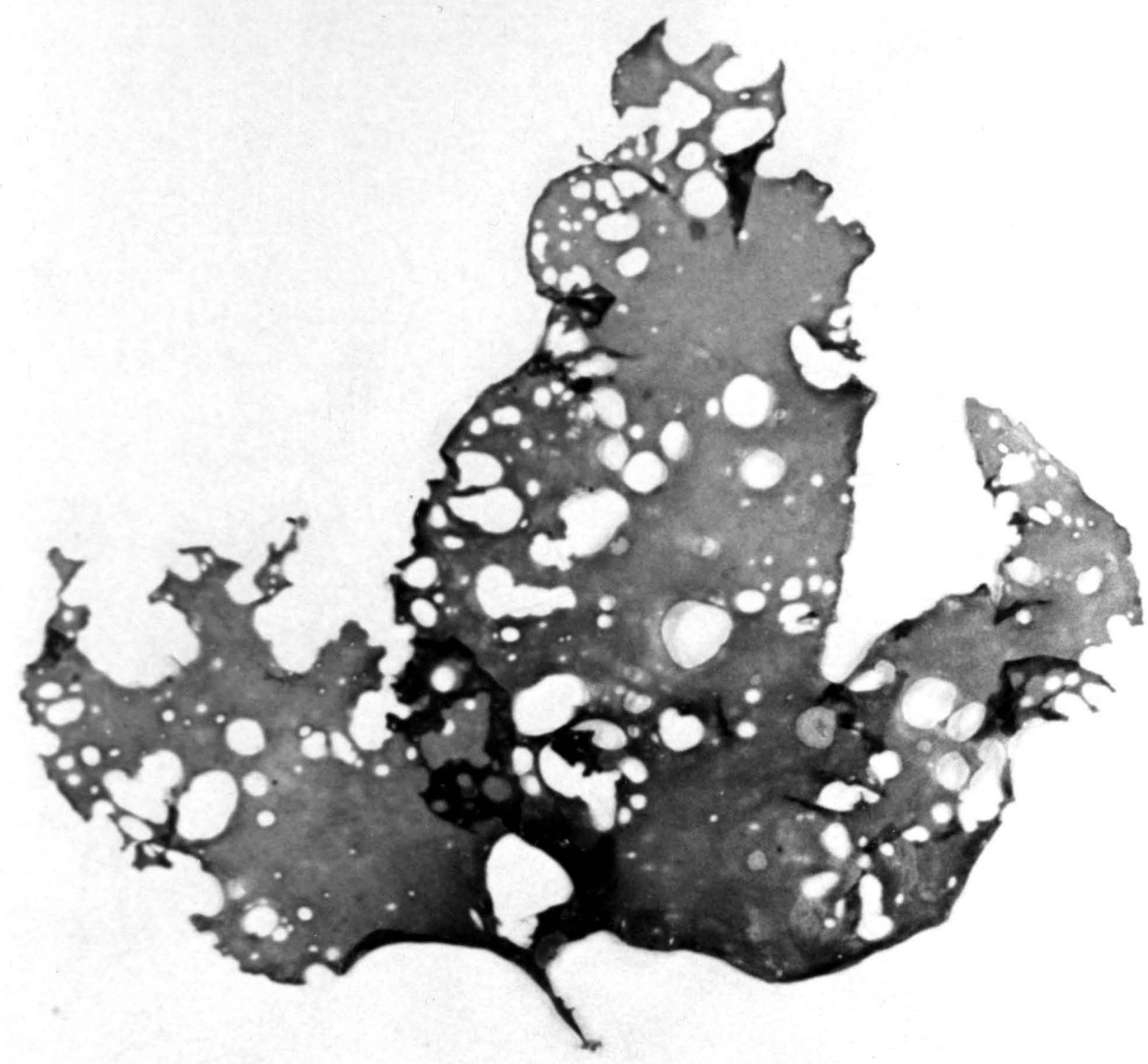

Herbarium of

Techaical Name IRIDAEA HETEROCARPR

Common Name IRIDESCENT SEACUEEO

family Groperinacese

Locality NETHRTS BAY, OREGON

Altitude $-1.5^{\prime}$

Collected by C.T.KuWERT

Identilied by B.E. Luperer

Date JuLY /2, 1971

Habitat ATTACHED

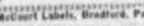

Figure 31. Inidges heterocarou. (K) 


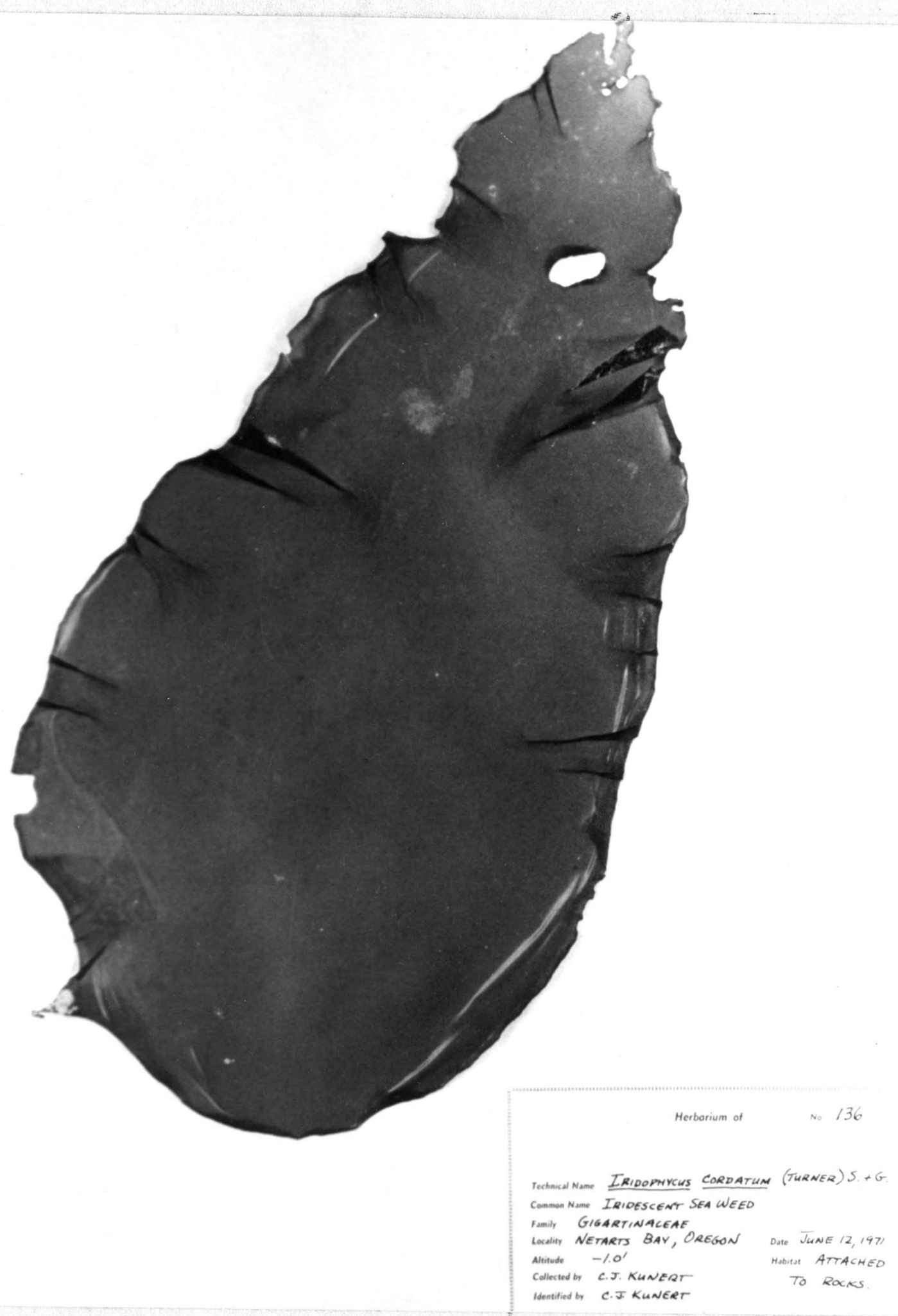

Figure 32. Inidaea cordata $(1 / 2 x)$ 


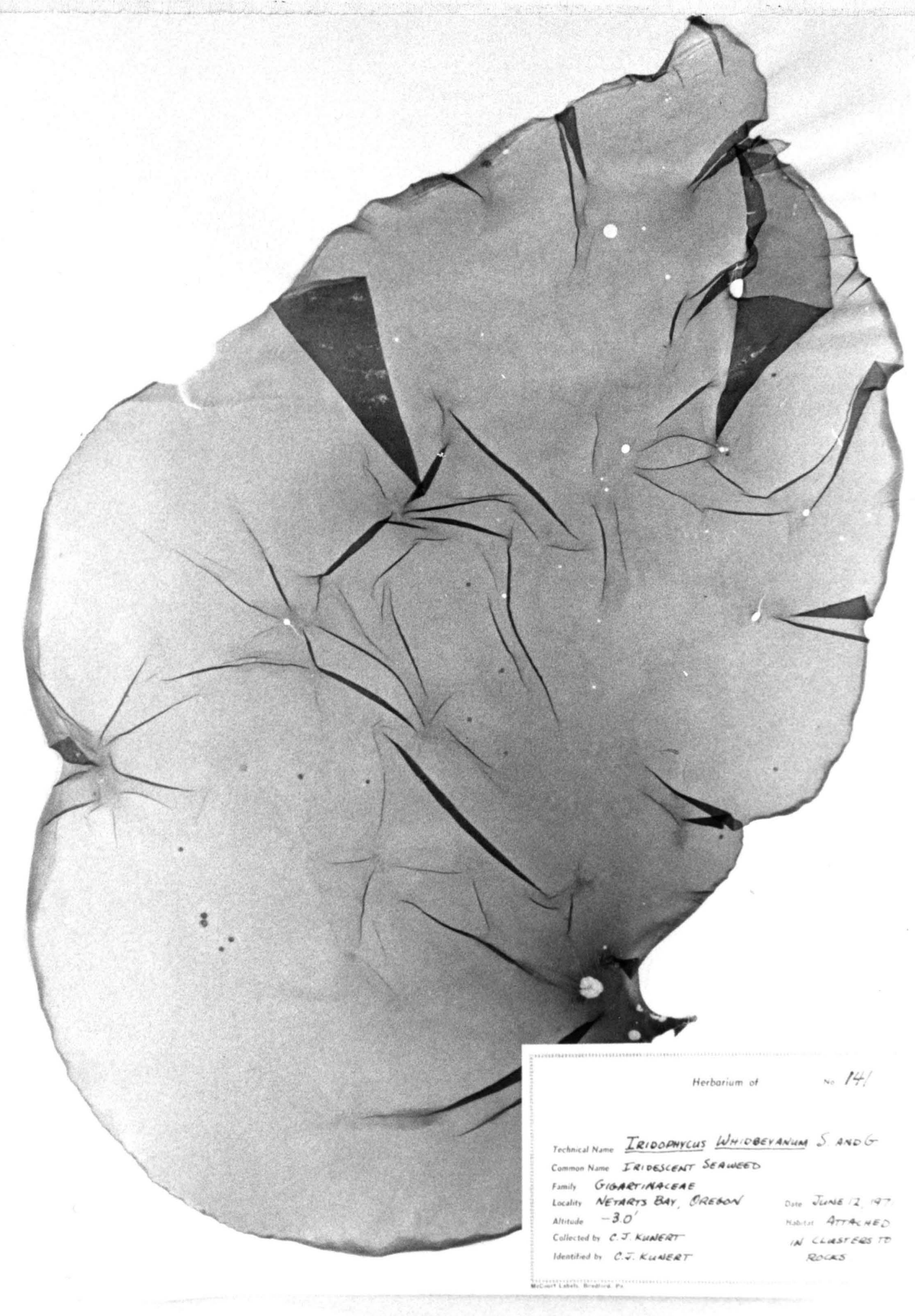

Pigure 33. Inidaea nidibeyana. (Ko) 
Collection number: 193.

Platythamion villosum Kylin

Found in association with Polysiphonia collinsii. Collected in zone 4 on Warch 13.

Snith (1944), p. 315 .

Collection number: 49.

Microcladia Greville

Key to the Species

Branching distichous and alternate

Branching unilateral and pectinate Branching unilateral and pectinate - . . . - . - Microcladia borealis $(2)$

(1) Microcladia coulteri Harvey

Common throughout the Bay on rocks or shells at the low tide line.

Smith (1944), p. 329.

Collection numbers: $15,18,19,72,130,151,192$.

(2) Microcladia borealis Ruprecht April 17.

One specimen washed ashore in zone 6 , collected on

Smith (1944), p. 330 .

Collection number: 73 .

Ptileta C. A. Agardh

Key to the Species

Margins of the ultimate branchlets smooth . . . . $\cdot$;

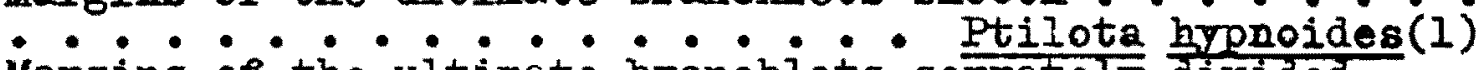
Margins of the ultimate branchlets serrately divided.

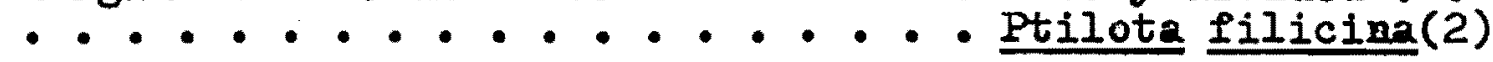

(1) Ptilota hypnoides Harvey

A single specinen found epiphytic on Corallina

officinalis $\mathrm{Y}$. chilensis. Collected July 9 in zone 1. Smith $(1944)$, p. 332

(2) Ptilota Pilicina (Farlow) J. Agardh collected twice, both times washed ashore near the boat jetties. Collected February 5 and July 9. Smith (1944), p. 333. Collection numbers: 20, 195.

Polyneura latissina (Harrey) Kylin Rare. Washed ashore high in the intertidal zone near the boat jetties. Collected only June 12 . 

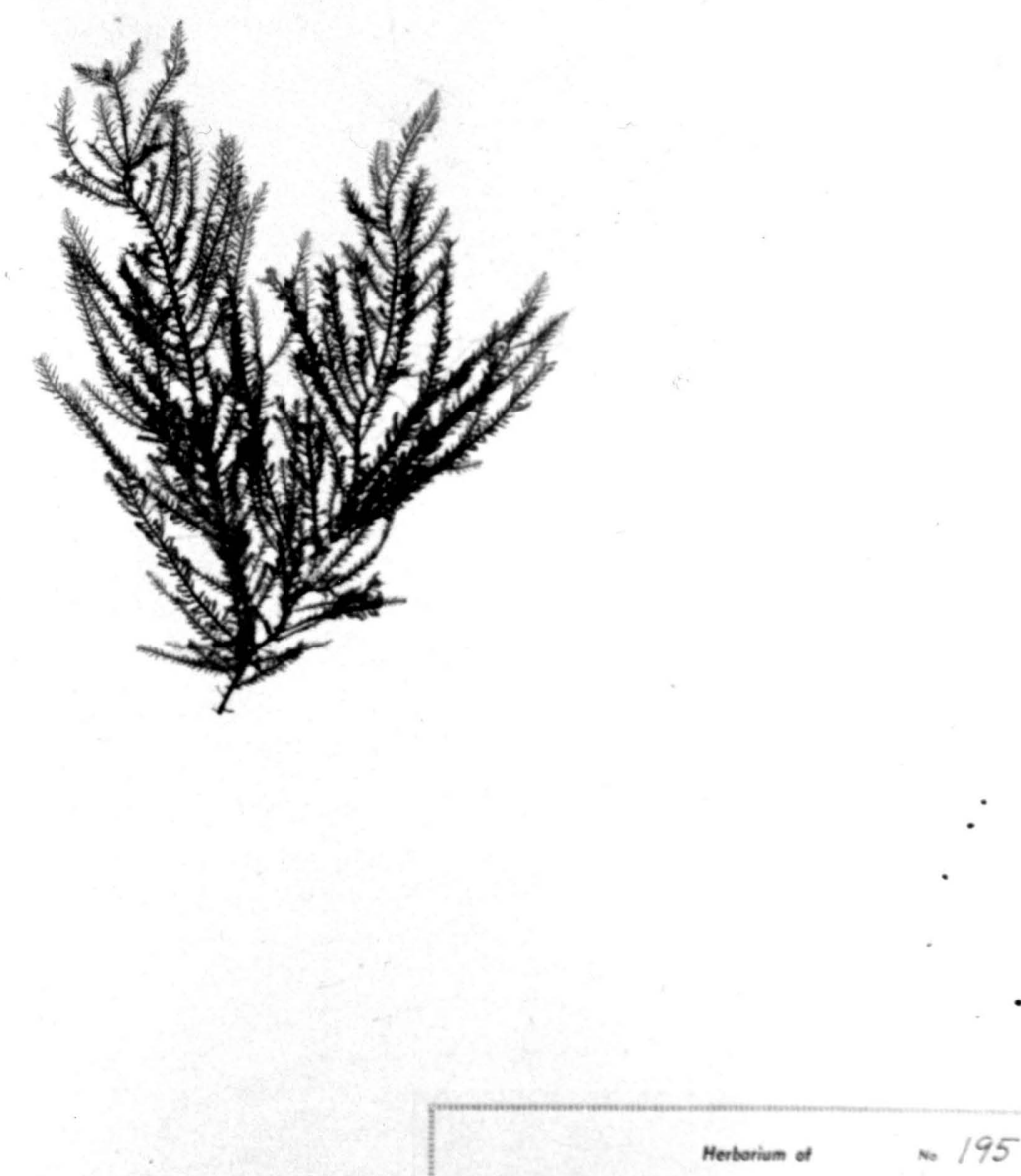

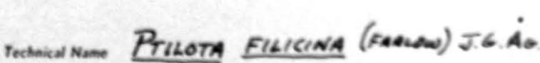

Commen Num RED Wive

funly Ceananiacene

locality Nerners Bar, Derwan

Alsiode Whasso Asmoes

Callectiod by C.: knweer

Dow Jear 9, 97

Itentified in Q.J. kuverer

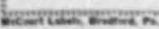

\section{Firues 34. Eulota filicina. $(1 / x)$}




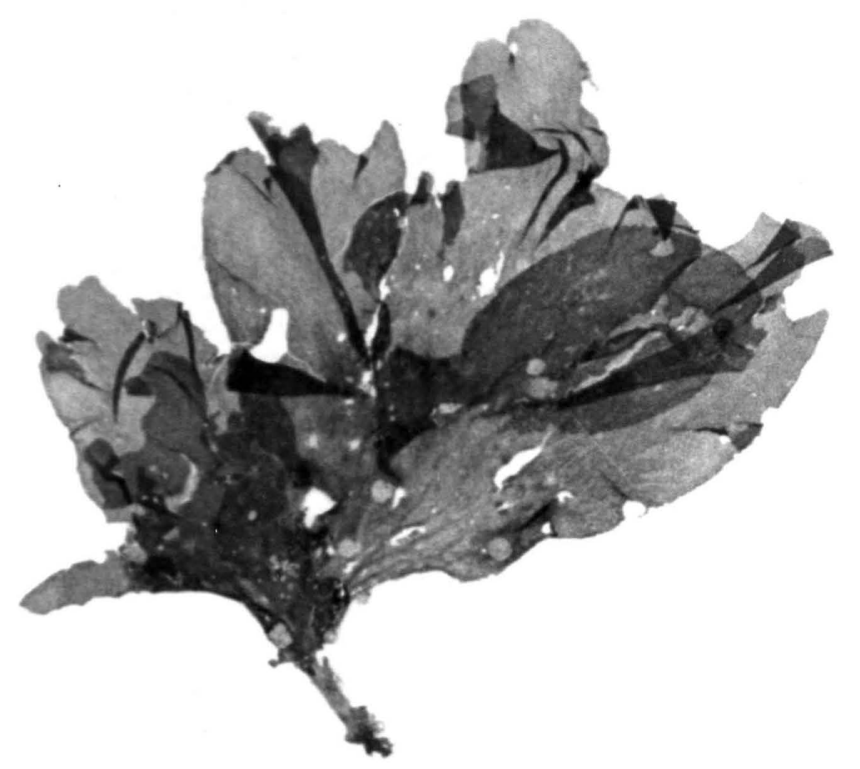

Herborium of No 126

Technical Name POLYNEURA LATISSIMA (HARVEY) KMLIN

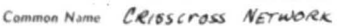

Family DELESSERIACEAE

Locaity NETARTS BAY, OREDON

Altitude CAST ASMOAE

Collected by C.J. Kunere?

Identitied by C.J. KunERT

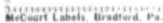

Pigure 35. Polyneura Latissing. (1/cx) 
Snith (1944), p. 341.

Collection number: 126.

Hrmenena Greville

Key to the Species

1. Tetrasporophytes with oval sori Hymenena setchellii(I)

1. Tetrasporophytes linear-elliptical. $\div . \cdots \cdot{ }^{\prime}$. 2. Thalli usually more than $15 \mathrm{~cm}$. . * *. . 2. Thaili usuailj iess than $\frac{\text { Eraenena }}{10}$ crabeiligere $(2)$ .......... Hyenena jyinii(j)

(I) Eymenene setchellii Gardner on rocks buried in sand at $-2.5^{\prime}$ in zone 1. Cig. 36 lected May 25. Smith (1944), p. 350 . Collection numbers: $103,120$.

(2) Hymenena flabelligera (J. Agardh) KJlih Fig. 37. Found washed ashore and epiphytic on Prionitis

andersonii. Collected in the vicinity of the boat jetty. Snith (1944), p. 348 .

Collection numbers: $112,127,181$.

(3) Hymenena kylinii Gardner Collected in the same locale and habitats as H. flabelifigera, but distinctly smaller in size. Smith (1944), p. 349.

Collection numbersL 99, 180.

Polysiphonia Greville

Key to the Species

1. Segments with four pericentral cells .......

*........ Pelysiphonia pacifica(1) i. Segments with more than four pericentral cells $\bullet 2$. 2. Trichoblasts and scar cells absent $\bullet \cdot \cdot \cdot \cdot \cdot \dot{*}$ - * * * - - Polysiphonia dictyurus (2) 2. Trichoblasts and scar cells present.$\cdot{ }^{*} 3$. 3. Trichoblasts and scar cells regularly occuring on

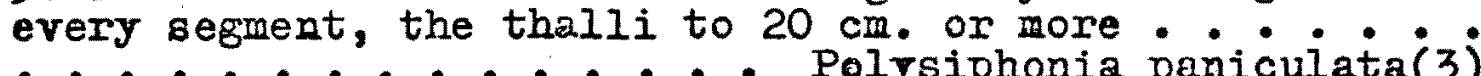
3. Trichoblasts and scar celis $\frac{\text { Polysiphonia }}{\text { less frequent, the thalii }}$ under $4 \mathrm{~cm}$. . . . . . Polysiphonia collinsii(4)

(1) Polysiphonia pacifica Hollenberg Uncomion on rocks near the mouth of the Bay. Smith (1944), p. 359.

Collection numbers: $7,10$. 


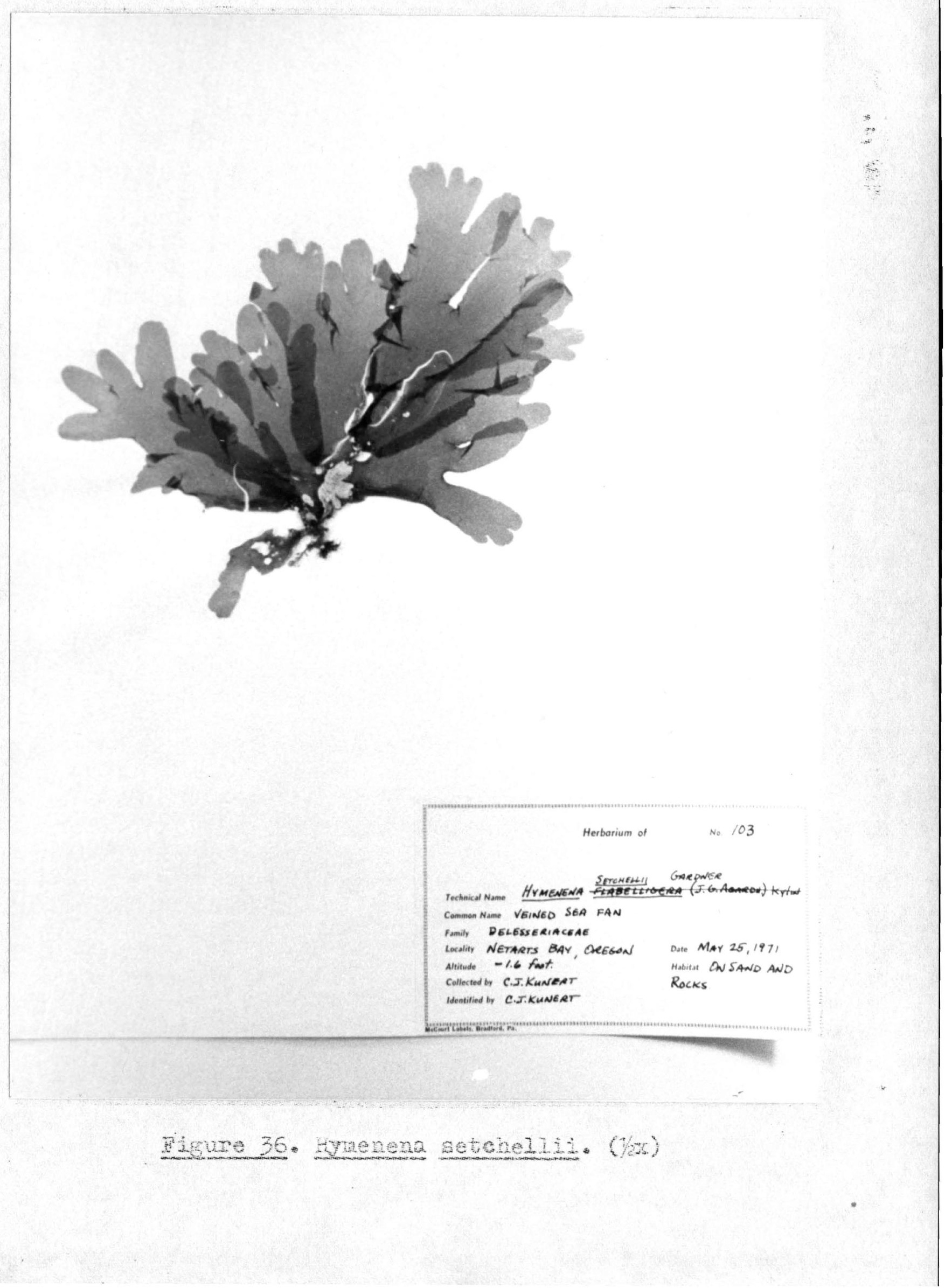




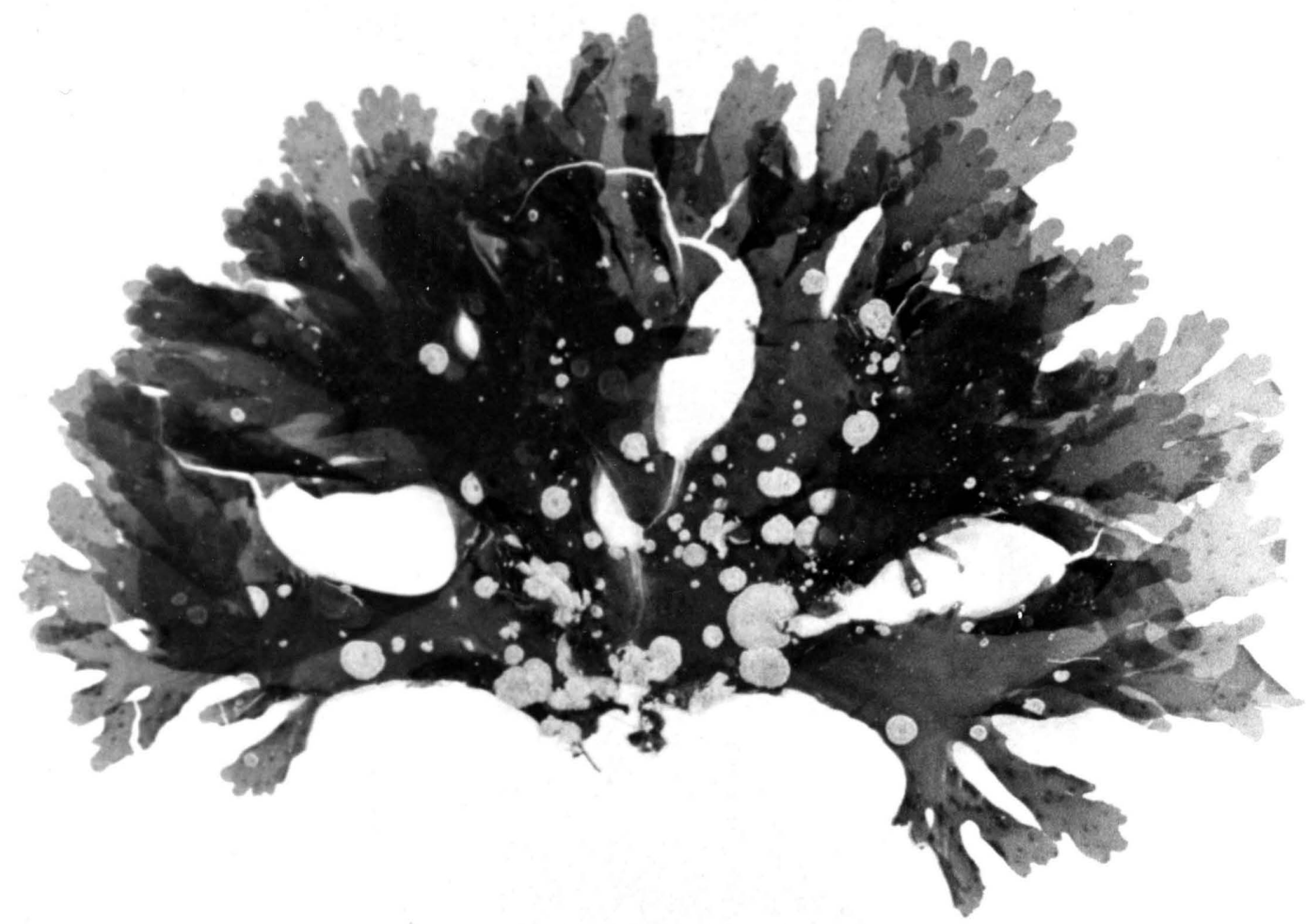

Herbarium of

No. $/ 8 /$

Techaical Name HYMENENA FLABELLIGERA (J. AG.) KYLIN Common Name VEINEO SEA FAN

Family DELESSERIACEAE

Locality NETARTS BAY OREGON Date TuLY 9,197

Altitude WASNED Asinore

Collected by C.J. KUNERT

Habitat?

Identilied by C.T. KUNERT

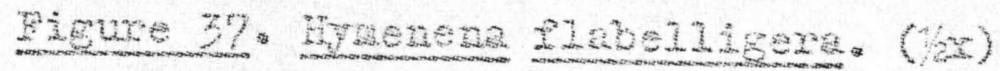




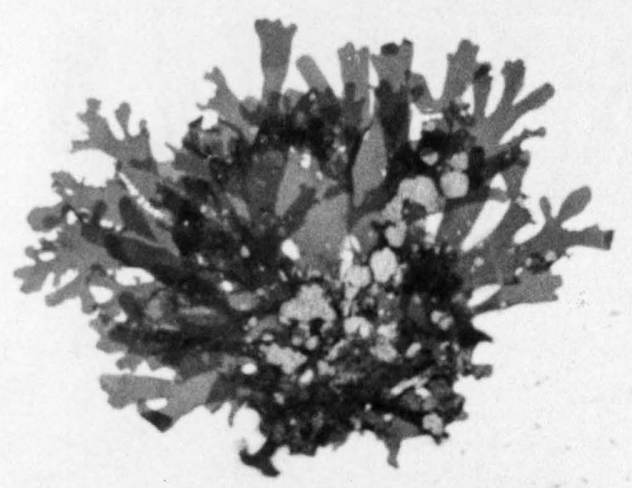

Herbarivem of

Ne. 180

TechondiNam HYMENENA KYLINII GAODNER

Comono Nus VEINEO SEA FA
fumily DELESSERIACEAE

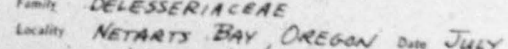

Alitude Whines Asindee

Collected by CIS. MuNEAT

latentied oy CI. KuNERT

Risure 38. Hynenena kylinii. (1/2x) 


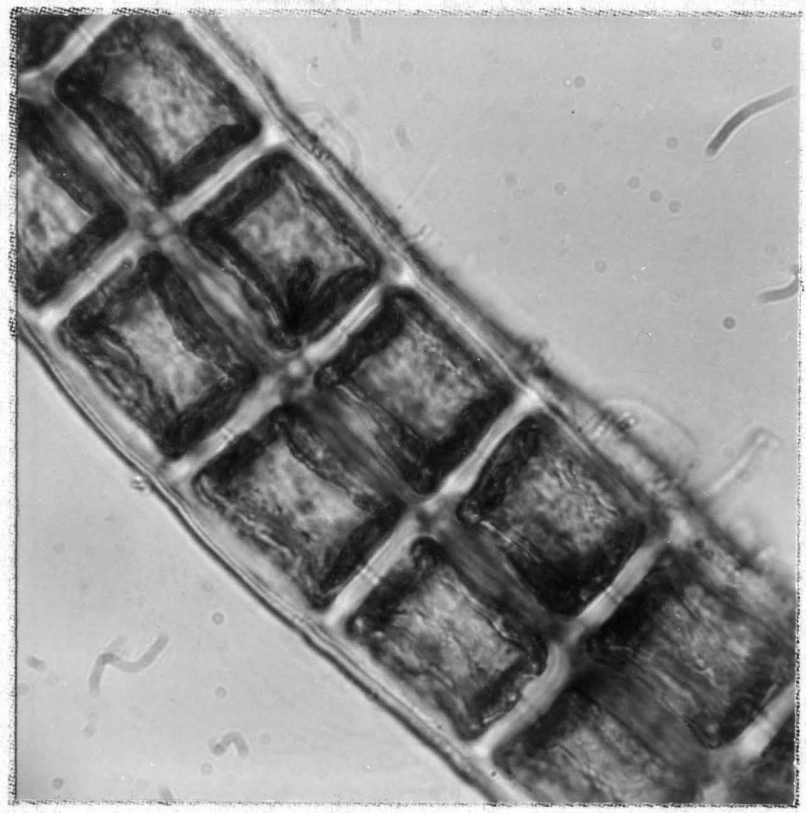

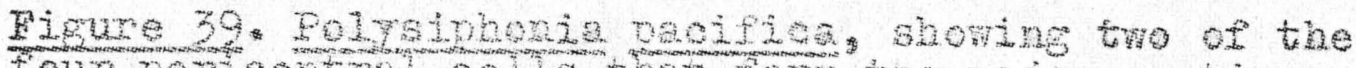

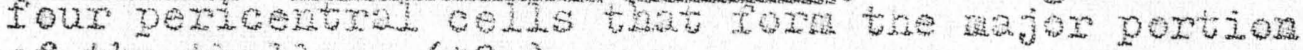
of the thallus. $(40 x)$

(2) Polysiphonia dictyurus J. Agardh

Rare on rocks in the zudflats of zone 4. Rough in texture. Collected on June 29.

Hollenberg (1944), p. 474 .

collection number: 170 .

(3) Polysiohonia paniculata Montagne Figs. 40, 41, +42. Very cormon throughout the say on rocks in the low intertidal to bigh littoral zones. The most comon species of Polysiphonia in vetarts bay. Hollenberes (1944), p. 474. Collection numbers: $85,86,152,156,161,166,194$.

(4) Polysiphonia collinsii Hollenberg

tidal to subtidal zone.

Hollenbers $(1944), \mathrm{p} \cdot 474$.

Collection numbers: $24,32,43,75,83,91,96,132$.

Pterosiphonia dendroides (Montagne) Falkenberg Fig. 43. Uncommon attached to rocks from -1.0 to $-3.0^{\prime}$.

collected on rocks from the boat jetties.

Snith (1944), p. 366.

Collection numbers: $14,139,190$. 


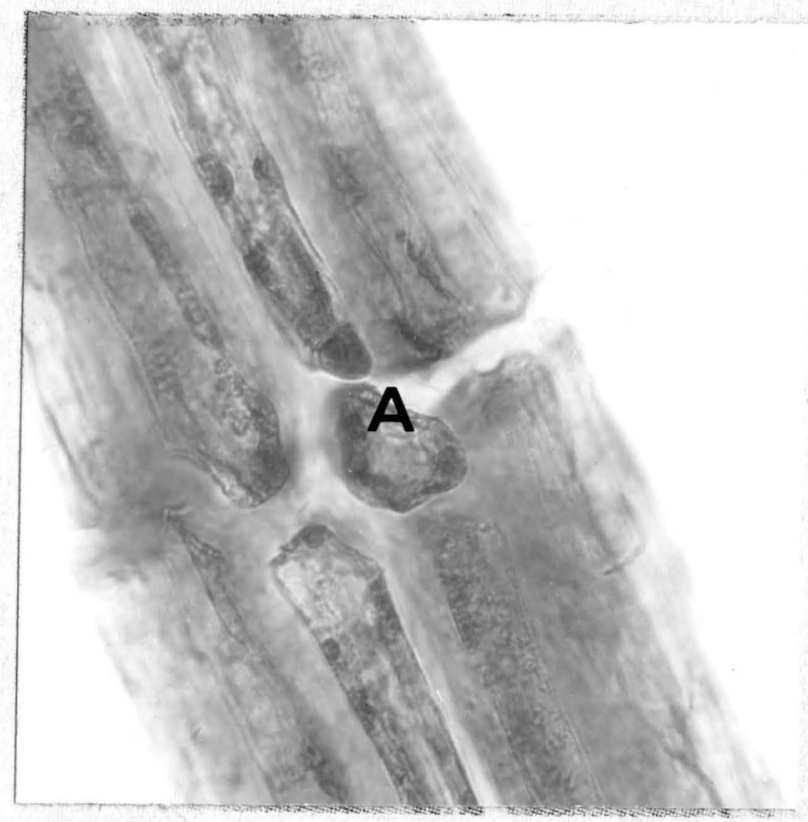

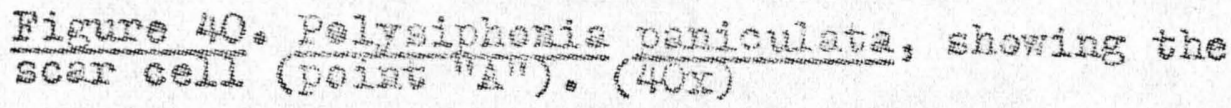

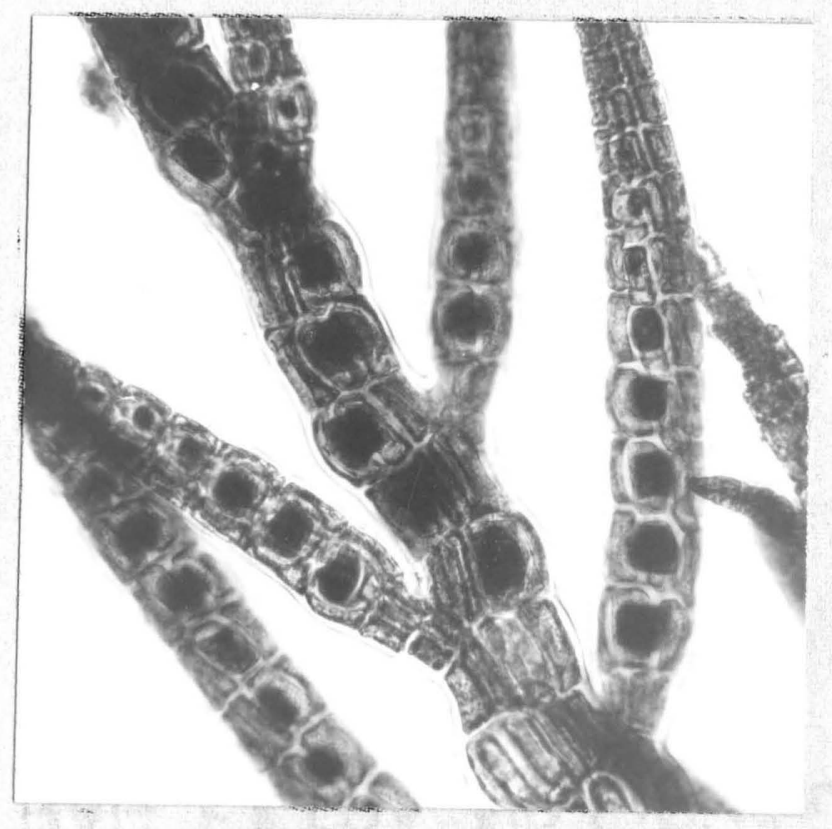

Figure 41. Polysiphonia paniculata, showing the
characteristic cortiguration on tetraspores. (10x) 


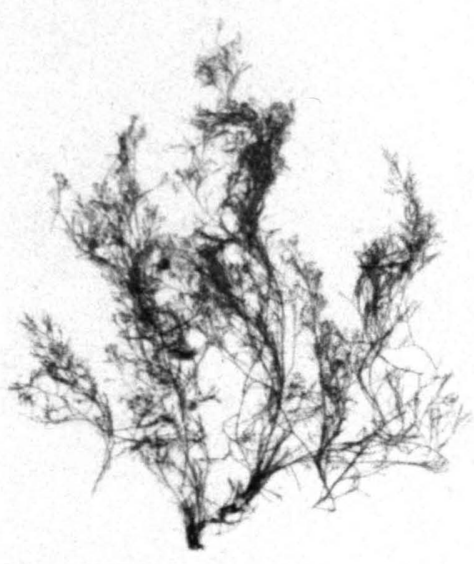

Herborium of 


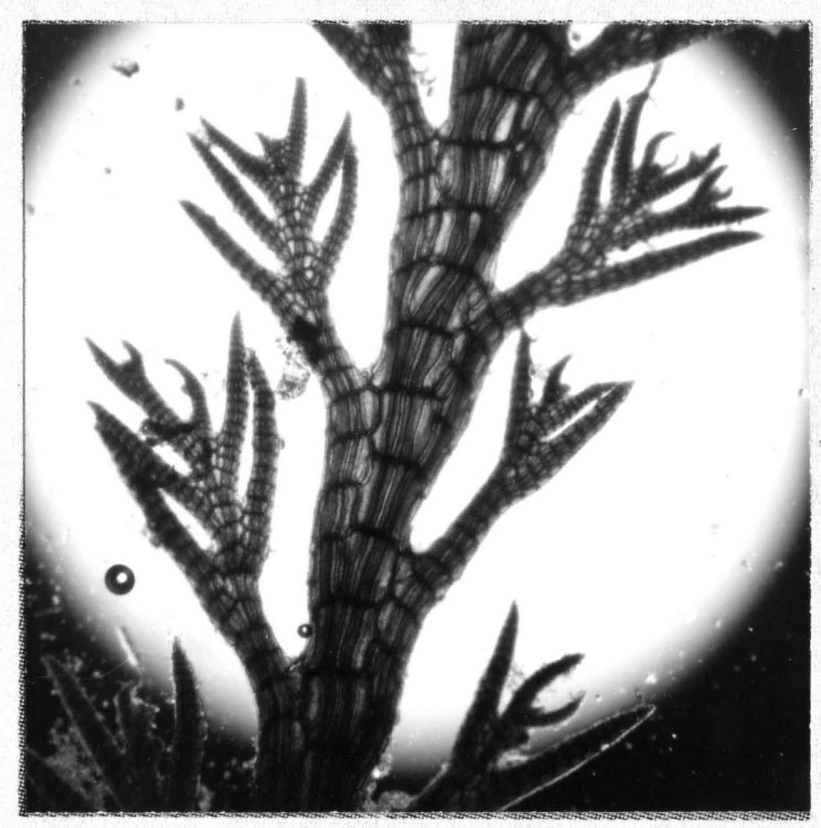

\section{Iigure 43. Pterosiphonia dencrojden. (2.5x)}

Odontha1122 Iyngbye

Key to the Species

Cystocamps over 0.5 man andaneter, branching profuse.

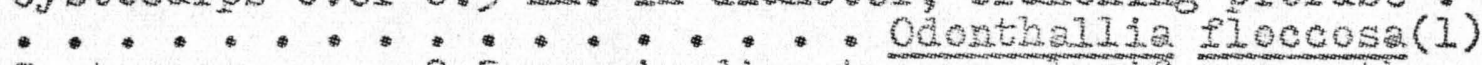
Cystocarps over 0.5 in. in dianeter rarely is ever, the branching more slender and less profuse odonthail orecona $(2)$

(1) Odonthallia floccosa (Bsper) Falkenberg Fig. 44. Very compon in the high littoral zones of the east side of the Bay. Collected fron May through July. Saith (1944), p. 375 . Collection numbers: $98,105,142,143,159$.

(2) Odonthal113 oregona Doty Fig. 45. Collected July I2 fron rocks along the boat jetty. At the low tide mark. These differ from 0 . floccosa in overall size, being ruch sialler. Doty $(1947), p \cdot 196$. collection number: 209.

Leurencia spectabilis Rostels and Ruprecht Rare in the intertidal zone on rocks. Collected only May 25.

Sinith (1944), p. 377 . Collection number: 118. 


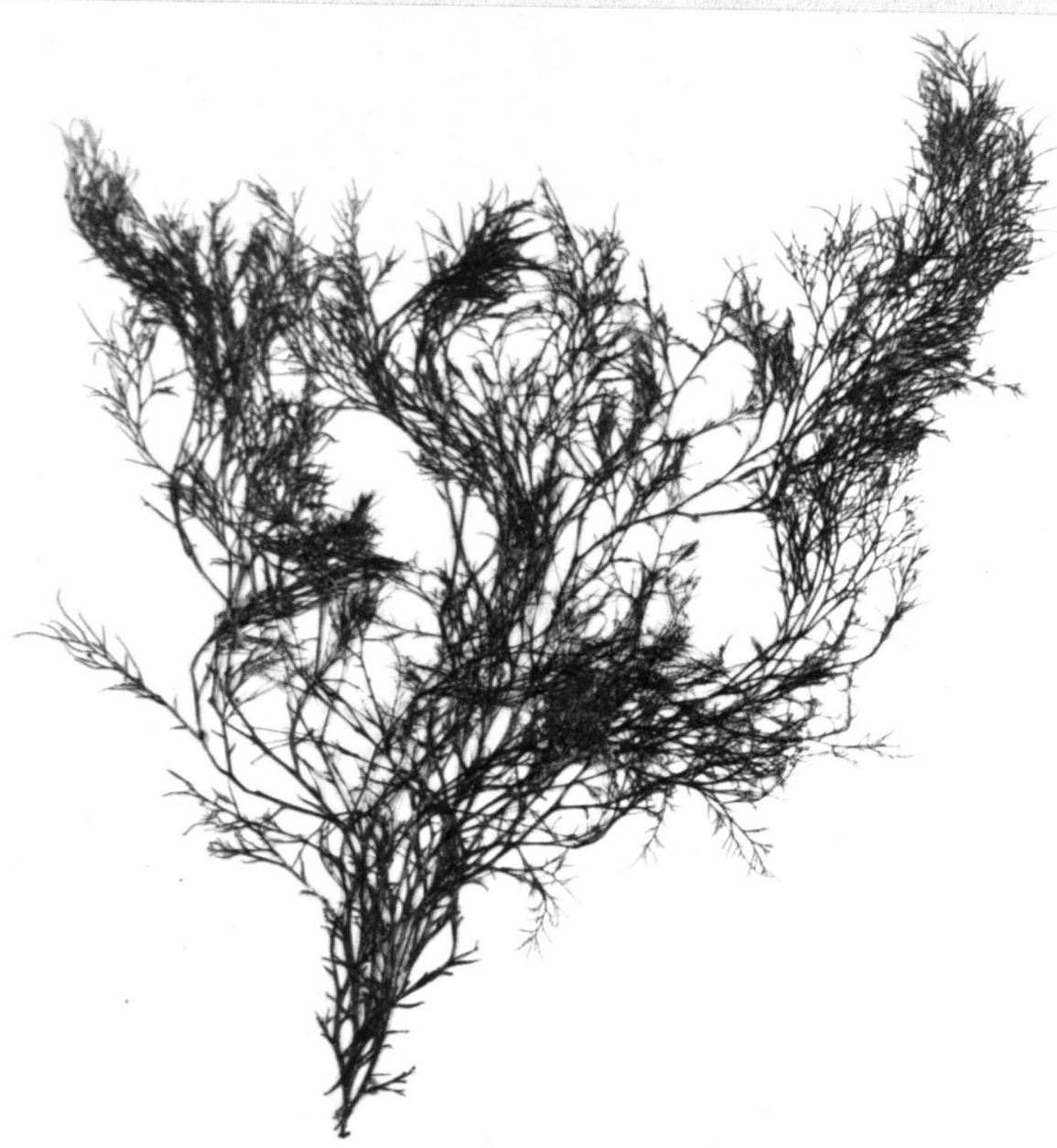

Herbarium of

No. 142

Technical Name OdONTHALLIA FLOCCOSA (ESPER) FALKENBERG

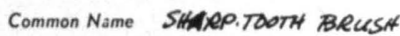

Family RHDDOMELACEAE

Locality NeTHETS BAY, ORGGON Date JuNE 12,197/

Altitude -1.0 fooT

Collected by C.T.KUNERT

Habitat ATTACHED TO

Identified by C.T. KUNERT ROCKS. 

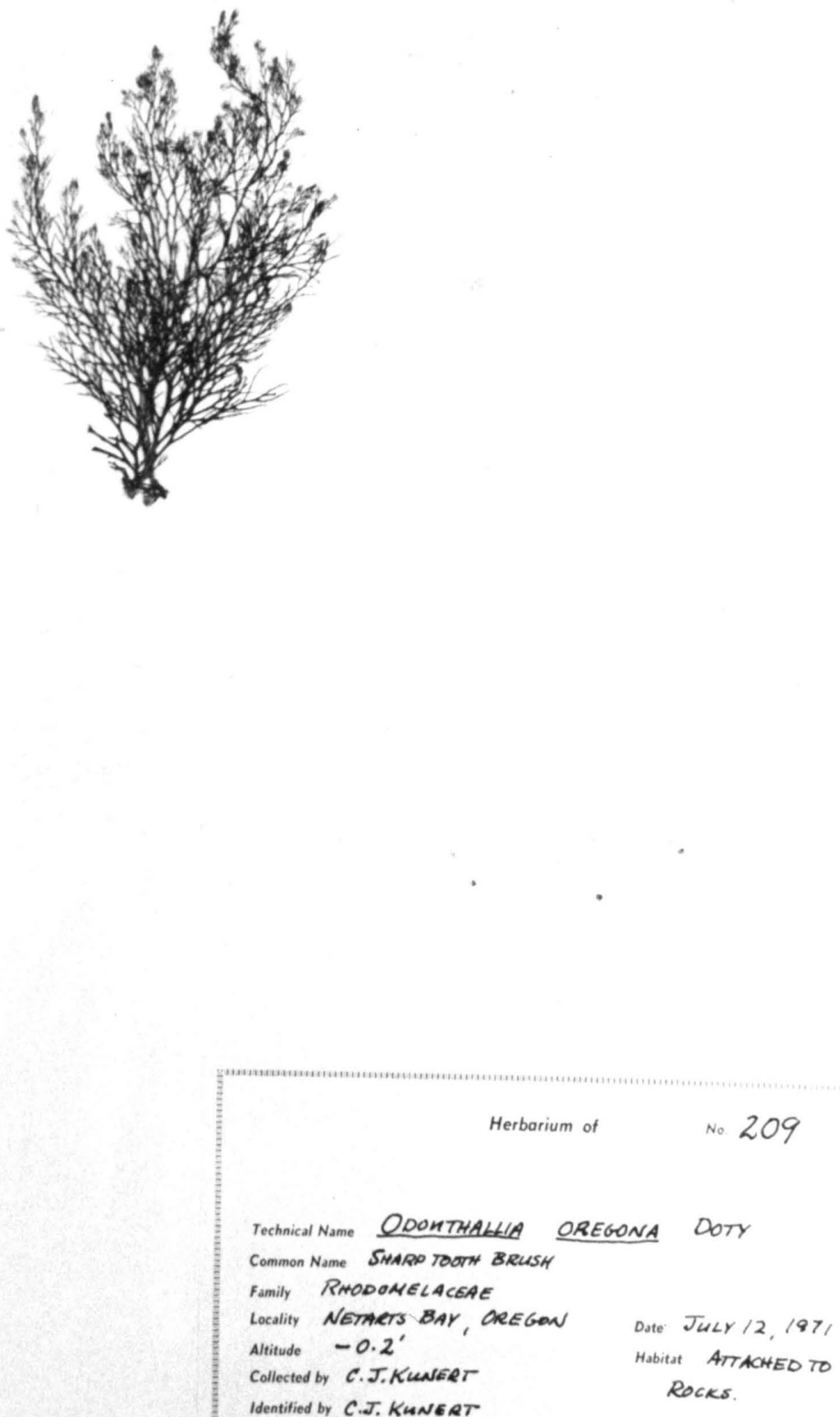

Figure 45. Ooonthallia oregona. (1/2x) 
The collection numbers referred to in the preceding annotated list of marine 2lgae are the author's. This collection is presently being housed at Concordia college, 2811 N. E. Holman, Portland, Oregon, 97211. 


\section{REFERINCES}

Abbott, Isabella A. 1961. "On Schinaelmannia from California and Japan." Pacific Naturalist. 2(2): 379386.

- 1965. "Studies on Callophyllis (Rhodophyceae) from the Pacific Coast of North America." Nova Hedwigia. 10(1/2): $67-84$.

- 1967. "Studies in some foliose red algae of the Pacific coast. I. Cryptonemiacere." Journal of Phycology. 3: 139-149.

- 1968. "Studies in some foliose red algae of the Pacific coast. III. Dumontiaceae, Weeksiacere, Kallymeniaceae." Ibid. 4: 180-198.

- 1969. "Some new species, new combinations, and new records of red algae fron the Pacific coast." Madroñe. $20(2)$.

Blackan, F. F. and A. G. Tansley. 1902. New Phytol. I: $17-24,47-48,67-72,89-96,114-120,133-144,163-$ $168,189-192,213-220,233-244$.

Chapman, V. J. 1962. The Algae. St. Martin's Press, New York.

Collins, F. S. 1928. Green Algae of North America. New York.

Davis, Charles C. 1955. Marine and Fresh-Hater Plankton. University of Hichigan Press.

Dawson, E. Yale. 1944. "The Marine Algae of the Gulf of California." Allan Hancock Pacific Expeditions. 3(10): $189-453$.

- 1946. A Guide to the Iiterature and Distributions of the Marine AIsae of the Pacific Coast of North America. (Reprinted from the Heroirs of the Southern (alifornia Academ of Sciences. Vol. 3. No. 1.)

- 1953."Marine red algae of Pacific Mexico, Part I. Bangiales to Corallinaceae Subf. Corallinoideae." Allan Hancock Pacific Expelitions. 17(1): 1-239. 
- 1954. "Marine red algae of Pacific Mexico, Part II. Cryptonemiales (cont.)." Ibid. 17(2): 241-397.

- 1956. How to Know the seaweeds. Wr. C. Brown Co.

- 1961a. "A guide to the literature and distributions of Pacific benthic algae from Alaska to the Galapagos Islands." Pacific Science. 15(3): 370-461.

- 1961b. "Marine red algae of Pacific Mexico, Part IV. Gigartinales." Pacific Naturalist. 2(5): 191-341.

- 1963a. "Marine red algae of Pacific Mexico, Part VI. Rhodrmeniales." Nora Hedwigia. 5: 437-476.

- 1963b. "Harine red algae of Pacific Mexico, Part VIII. Ceramiales: Ceraniaceae, Rhodomelaceae." Ibid. ㄷ: $401-481$.

Dixon. 1961. "On the Classification of the Florideae." Bot. Mar. 3(1): 1-16.

Doty, M. S. 19472. "The marine algae of Oregon, Part I. Chlorophyta and Phaeophyta." Farlowia. 3(1): 1-65.

- 19470. "The marine algae of Oregon, Part II. Rhodophyta." Farlowia. 3(2): 159-215.

Farlow, W. G. 1875. "List of the Marine Algae of the U. S. with Notes." Froceedings of the American Academy of Arts and Sciences. 10(n.s.2): $351-380$.

Fritsch, F. E. 1935. The Structure and Reproduction of the Algae. Cambridge. Volume 1.

- 1944. Botanical Review. 10: 233-277.

- 1945. The Structure and Reproduction of the Algae. Cambridge. Volume II.

Gardner, N. L. 1926. "New Rhodophyceae from the Pacific Coast of North Anerica. I." University of Celifornia Publications in Botany. 13: $205-226$.

- 1927. "New Rhodophyceae Irom the Pacific Coast of North America. II." Ibid. 13: 235-272.

- 1927. "New Rhodophyceae from the Pacific Coast of North America. III." Ibid. 13: 333-368.

- 1927. "New Rhodophyceae from the Pacific Coast of North America. IV." Ibid. 13: 373-402. 
- 1927. "New Rhodophrceze from the Pacific Coast of North America. V." Ibid. 13: 403-434.

- 1927. "New Rhodophycere from the Pacific Coast of North America. VI." Ibid. 14: 99-138.

Guberlet, M. I. 1956. Seaweeds at Ebb Tide. University of Washington Press. SeatEIe.

Hollenberg, G. J. 1943. "New narine algae from Southern California. II." American Journal of Botany. 30: 571-579.

- 1944a. "An account of the species of Polysiphonia on the Pacific Coast of North America. I. Oligosiphoni2." Ibid. 29: 772-779.

- 1944b. "Anaccount of the species of Polysiphonia on the Pacific Coast of North Aneric2. II. POIJsiphonia." Ibid. 31: 474-480.

Hollenberg, G. J. and Isabella A. Abbott. 1965. "New species and new combinations of marine algae from the region of Monterey, California." Canadian Journal of botany. 43: $1177-1188$.

- 1966. Supplement to Smith's Marine Algae of the Monterey Peninsula. Stanford University Press.

- 1968. "New species of marine algae fron California." Canadian Journal of Botany. 46: 1235-1251.

Hus, H. T. A. 1902. "An account of the species of Porphyra found on the Pacific Coast of North America." Proceedings of the California Acadery of Sciences. 3a, ser. 2: $173-340$.

Kylin, H. 1925. The Marine Red Algae in the Vicinity of the Biological Station at Friday Harbor, Washington. Iund Univ. Arsskr, Sweden, C.W.K., Gleorup.

- 1937. "Anatorie der Rhodophrcean." In K. Linsbauer. Handbuch der Pflanzen-Anatonie. 6: Bd.2. 1-347.

Newell, G. E. and R. C. 1963. Marine Plankton: A Practical Guide. Hutchinson Education Ltd. Great Port Iand St. London.

Papenfuss, G. F. 1966. "Review of Florideophrcidae." Phycologia. 5: 247-256. 
Prescott, G. W. 1968. The Algae - A Review. Bost on, Houghton-ififlin.

Samborn, E. I. and M. S. Dety. 1944. The larine Algae of the Coos Bay - Cape Arago Region of Oregon. Oregon State Wonographs. Studies in Botany. No. 8.

Scagel, R. 1957. An Annotated List of the Marine Algae of British Colunbia and Northern Washinston. National luseurn of Canacia. Bulletin No. 150 .

- 1966. Marine Algae of British Columbia and Northern Washington. part I: Chlorophyceae. Ibid. Bulletin No. 207.

- 1967. Guide to Common Seaweeds of British Colurbia. British Columia Provincial Huseum. Department of Recreation and Conservation. Handbook No. 27.

Setchell, W. A. and N. I. Gardner. 1903. Algae of Northwestern Anerica. University of California Press, Berkeley, California.

- 1919-1920. The Marine Algae of the Pacific coast of North Amerioa. Ibid.

- 1933. "A Preliminary survey of Gigartina." University of California Publications in Botany. I7: 255-340.

- 1937. "Iridophycus in the Northern Hemisphere." Proceedings of the National Academy of Sciences. 23: $169-174$.

Smith, G. M. 1944. Marine Algae of the Monterey Peninsula, California. Stanford University, California.

- (ed.) 1951. Manual of Phycology. Chronica Botanica ce. Walthan, Hass.

- 1955. Cryptoganic Botany. Voluae I: Algae and Fungi. HeGraw-Hill Book co., Inc. New York.

Swith, G. M. and G. J. Hollenberg. 1943. "On Some Rbodophyceze from the Monterey Peninsula of California." American Journal of Botany. 30: 211-222.

Tilden, Josephine E. 1935. The Algae and Their Iife Relations. Hinneapolis. 
APPENDIX

EEY TO THE GENERA

Dirision: Chlorophyta

1. Thallus a simple or branched filanent . . . . . 2 .

1. Thallus not filamentous ............... . 5 .

2. Filaments branching... . . . . . . . 4.

2. Filaments unbranched ............ 3 .

3. Filareats entangled in nats that are prostrate. : :

- * * * * * * * * Rhizoclonium, p. 12

3. Filaments attached, not bent and entangled with one

another ............... Ulothrix, p. 23

4. Filaments in rope-like strands held together by

recurved branches . . . . . Spongomorpha, p. 14

4. Filaments repeatedly branched, but not in rope-

like strands . . . . . . Cladophora, p. 12

5. Thallus 1 cell in thickness. - - Monostroma, p. 14

5. Thallus 2 cells in thickness.$\cdot \cdot \cdot \cdot{ }^{\circ}$

6. No open space between the two cell lajers...

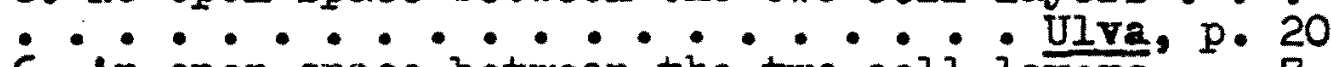

6. An open space between the two cell layers. . 7.

7. Thallus markedly flattened - - Enteromorpha, p. 17

7. Thallus cylindrical, arising from a discoid base :

.............. Blidingia, p. 15

\section{Division: Phaeophyta}

1. Thallus filamentous ... . - Ectocarpus, p. 25

1. Thallus not filamentous ........... 2. Thallus blade-like, usually simple ... 3 .

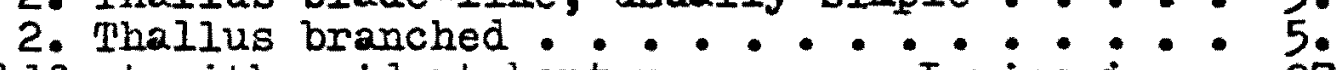

3. Holdfast with evident haptera $\because$ Ianinaria, p. 27

3. Holdfast without haptera.$\cdots 4$.

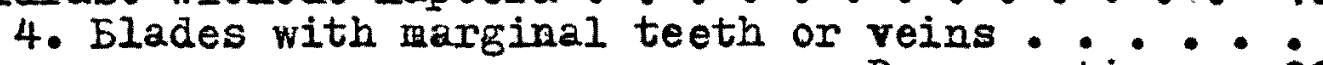

. * . *.... Desmerestia, p. 26

4. Blades without marginal teeth or veins? ?

5. Thailus fiattened with dichotomous branching throughout

• • • • • • • . . - Fucus, p. 30

5. Thallus not flattened, blades borne radially about axis

•.............. Sargassum, p. 30 
Dirision: Rhodophrta

1. Thallus stony, impregnated with lime ...... 2 . 1. Thallus not stony, not impregnated with lime ... 4 . 2. Thallus wholly crutose and prostrate... 3 . 2. Thallus with erect, jointed shoots . : : 3. 3. Thallus thick and stony, comonly covering rocks and shells . . . . . . . Iithothamnion, p. 33 3. Thallus forming a thin crust of small diameter, usualiy epiphytic $\cdot \cdots \cdot \cdot \cdot \cdot \cdot$ Dermatolithon, p. 33 4. Thallus 2 simple or branched filarient . ? ? 4. Thallus not filamentous . . . . . 5. 5. Thallus a blade one or two cells in thickmess $\because 6$. 5. Thallus more than two cells in thickness $\cdot \because \because 9$. 6. Thallus epiphytic on eelgrass, blade usually less than 1 crn. long . - - Smithora, p. 30 6. Thallus not epiphytic, blade over $8 \mathrm{~cm}$. tall . .............. Porphyra, p. $30^{\circ}$ 7. Thailus a simple filament ..... Bangia, p. 30 7. Thallus a branched filament . . . . 8 . 8. Each verticel with all branchlets the same length •......... Antithamnion, p. 46 8. Each verticel with two iong and two short length branchlets ....... Platythamnion, p. 50 9. Thallus cells in regular transverse series . ? 10 . 9. Thallus cells not in a regular transverse series: Il. 10. Branches cylindrical and radially disposed. io: Branches more or less flattentysiphonia, p. 53 11. Thalius cylindrical or 2 slightly flattened cyind 57 usually nore or less branched . . . 11. Thallus neither cylindrical nor a slightiy flattened cylinder .................... 19. 12. Branching dichotomous, branches stiff and wiry

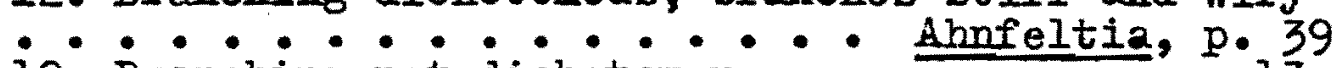
i2 Branching not dichot omous: 13. Thallus with a few long branches, rarely short branching . * . . . . - Gracilariopsis, p. 36 13. Thallus with many branches. .14. 14. Major branches vith many short lateral braches, all approximately the same length ..... 15. 14. Major branches with progressively shorter branches . . . . . . . . . . . . 16. 15. Short branches flattened and resembing minute leaves is - $\cdot$ - * - - - - - Ptilota, p. 50 15. Short branches sharpiy pointed, more or less distichous and compressed...... Odonthallia, p. 60 
16. Branching of smaller branches pectinate . 17. 16. Branching of smaller branches not pectinate 18. 17. Pectinate branches incurved toward apex of branch bearing therk .......... Plocamium, p. 36 17. Pectinate branches curving away from apex of branch bearing them . - . . . Microcladia, p. 50 18. Apices of branches acutely pointed . ? - * - * - - - Cryptosiphonia, p. 33 18. Apices of branches rounded - Laurencia, $p .60$ 19. Thallus with a single, undivided blade but at times with proliferous blades from the margin, the blade being

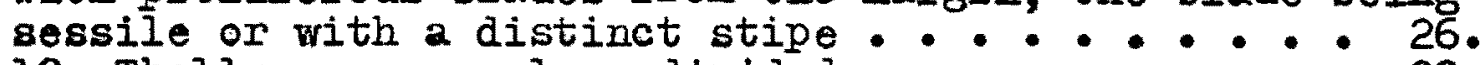
19. Thallus more or less divided . . . : : : $: 20$. 20. Divisions of thallus dichotomous . : : : 21 . 20. Divisions of thallus not dichotomous : : 23 . 21. Surface of dichotomies with many papillate outgrowths - • • • • • • • • • - Gigartina, p. 39 21. Surface of dichotomies without papillate outgrowths

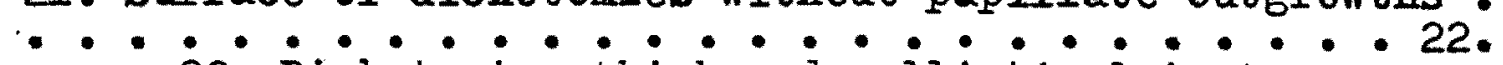
22. Dichotomies thickened, elliptical in transverse section . . . . . . Gymogongrus, p. 39 22. Dichotomies flattened, fan-shaped $\cdot: \cdot \cdot$ - * - * Callophyilis, p. 36 23. Flattened portion of thallus with a rarib, veins, or

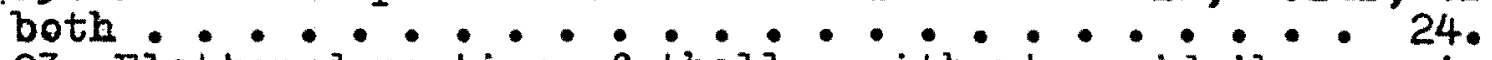
23. Flattened portion of thallus without 2 midrib or veins - . . 25. 24. Blade almost entire, with conspicuous anastomising veins $\ldots \cdots \cdots$ 24. Blade mostly not entire, with inconspicuous veins .............. Hypenen, p. 53 25. Flattened surfaces of thallus covered $\frac{1}{\text { with papillate }}$ outgrowths ........... Gigartina, p. 39 25. Flattened surfaces smooth, blade segments all about the same length ......... Prionitis, p. 36 26. The surface of the biade covered with papiliate outgrowths ........ Gigartina, p. 39 26. Flattened surfaces smooth . …. 27. 27. Leaf-like lobes of the thallus somewhat pointed $\cdots$

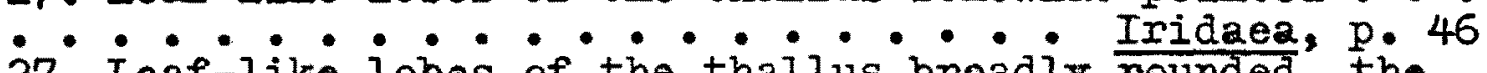
27. Leaf-like lobes of the thailus broadiy rounded, the stipe of erect shoots flattened . - Rhodoglossure, p. 40

Note: The above keys are an adaptation of the key to the genera found in Smith (1944), pp. 400-412. 